\title{
Identification of anthropogenic and natural inputs of sulfate into a karstic coastal groundwater system in northeast China: evidence from major ions, $\delta^{13} \mathrm{C}_{\mathrm{DIC}}$ and $\delta^{34} \mathrm{~S}_{\mathrm{SO}_{4}}$
}

\author{
Dongmei Han ${ }^{1}$, Xianfang Song ${ }^{1}$, and Matthew J. Currell ${ }^{2}$ \\ ${ }^{1}$ Key Laboratory of Water Cycle \& Related Land Surface Processes, Institute of Geographic Sciences and Natural Resources \\ Research, Chinese Academy of Sciences, Beijing, 100101, China \\ ${ }^{2}$ School of Civil, Environmental and Chemical Engineering, RMIT University, Melbourne, 3001 Victoria, Australia
}

Correspondence to: Dongmei Han (handm@igsnrr.ac.cn)

Received: 16 August 2015 - Published in Hydrol. Earth Syst. Sci. Discuss.: 3 November 2015

Revised: 23 March 2016 - Accepted: 25 April 2016 - Published: 17 May 2016

\begin{abstract}
The hydrogeochemical processes controlling groundwater evolution in the Daweijia area of Dalian, northeast China, were characterised using hydrochemistry and isotopes of carbon and sulfur $\left(\delta^{13} \mathrm{C}_{\mathrm{DIC}}\right.$ and $\left.\delta^{34} \mathrm{~S}_{\mathrm{SO}_{4}}\right)$. The aim was to distinguish anthropogenic impacts as distinct from natural processes, with a particular focus on sulfate, which is found at elevated levels (range: 54.4 to $368.8 \mathrm{mg} \mathrm{L}^{-1}$; mean: $174.4 \mathrm{mg} \mathrm{L}^{-1}$ ) in fresh and brackish groundwater. The current investigation reveals minor seawater intrusion impact (not exceeding $5 \%$ of the overall solute load), in contrast with extensive impacts observed in 1982 during the height of intensive abstraction. This indicates that measures to restrict groundwater abstraction have been effective. However, hydrochemical facies analysis shows that the groundwater remains in a state of ongoing hydrochemical evolution (towards $\mathrm{Ca}-\mathrm{Cl}$ type water) and quality degradation (increasing nitrate and sulfate concentrations). The wide range of $\mathrm{NO}_{3}$ concentrations $\left(74.7-579 \mathrm{mg} \mathrm{L}^{-1}\right)$ in the Quaternary aquifer indicates considerable input of fertilisers and/or leakage from septic systems. Both $\delta^{13} \mathrm{C}\left(-14.5\right.$ to $-5.9 \%$ ) and $\delta^{34} \mathrm{~S}_{\mathrm{SO}_{4}}$ $(+5.4$ to $+13.1 \%)$ values in groundwater show increasing trends along groundwater flow paths. While carbonate minerals may contribute to increasing $\delta^{13} \mathrm{C}_{\text {DIC }}$ and $\delta^{34} \mathrm{~S}_{\mathrm{SO}_{4}}$ values in deep karstic groundwater, high loads of agricultural fertilisers reaching the aquifer via irrigation return flow are likely the main source of the dissolved sulfate in Quaternary groundwater, as shown by distinctive isotopic ratios and a lack of evidence for other sources in the major ion chemistry. According to isotope mass balance calculations, the fer-
\end{abstract}

tiliser contribution to overall sulfate has reached an average of $62.1 \%$ in the Quaternary aquifer, which has a strong hydraulic connection to the underlying carbonate aquifer. The results point to an alarming level of impact from the local intensive agriculture on the groundwater system, a widespread problem throughout China.

\section{Introduction}

Degradation of groundwater quality, including salinisation, has become an increasingly serious global problem in coastal aquifers worldwide in recent years. With rapid economic development, population growth and increasing demand for freshwater resources, extensive groundwater withdrawals in these areas have led to water level declines and increasing groundwater salinisation (e.g. Barlow and Reichard, 2010; Han et al., 2015). Many previous studies have investigated the mechanisms of salinisation and potential sources of groundwater salinity in coastal aquifers, which can include evaporite mineral dissolution (e.g. Cardenal et al., 1994; Najib et al., 2016), downward/upward saline groundwater seepage (e.g. Guo et al., 1995; de Louw et al., 2013), brine migration (e.g. Han et al., 2011; Myshakin et al., 2015), and mixing caused by poorly constructed wells (e.g. Aunay et al., 2006), as well as "classic" seawater intrusion (e.g. Daniele et al., 2013).

Coastal areas are often sites of intensive human activity, including urbanisation and agriculture. Intensive agriculture 


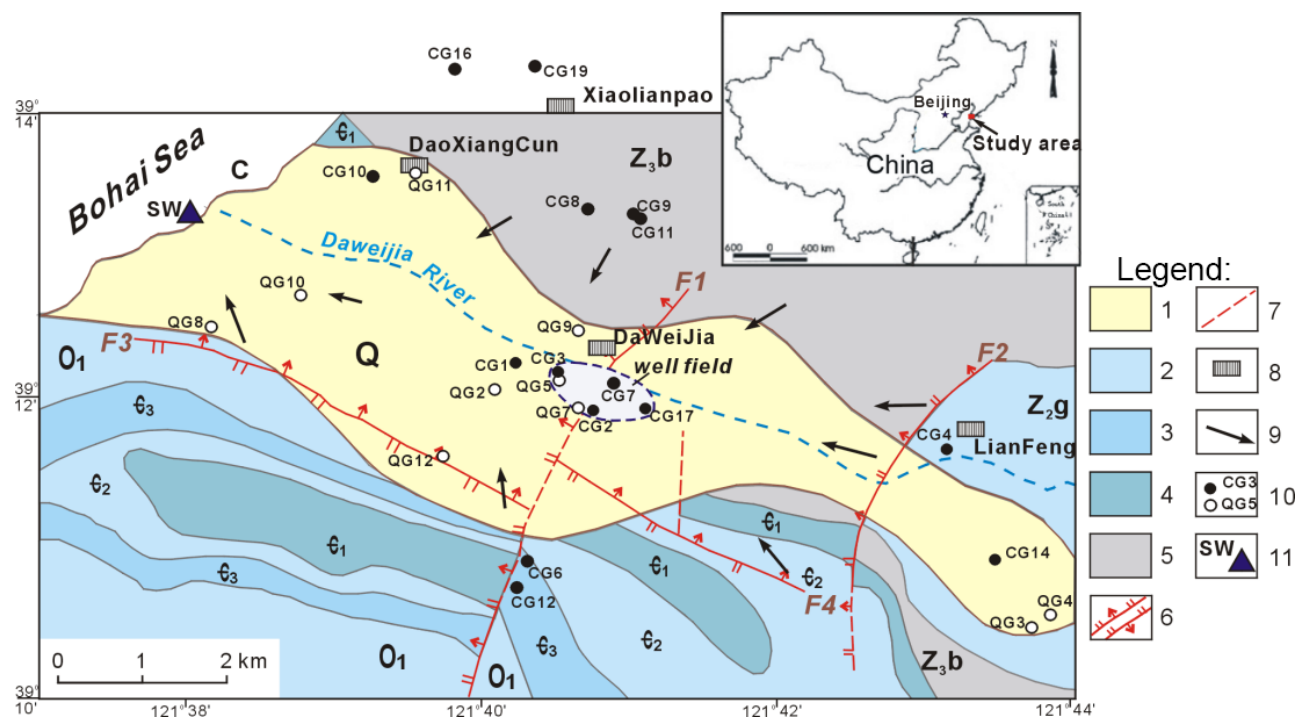

Figure 1. Geological setting and water sampling locations. Geology modified after Wu and Jin (1990). Formation note: $\mathrm{O}_{1}-\mathrm{Lower}_{\mathrm{O}} \mathrm{Or}^{-}$ dovician; $\epsilon_{3}$ - Upper Cambrian; $\epsilon_{2}-$ Middle Cambrian; $\epsilon_{1}-$ Lower Cambrian; $Z_{2} g-$ Ganjingzi group of Middle Sinian; $Z_{3} b-$ Beishan group of Upper Sinian. Legend: 1 - Quaternary sediments; 2 - thick-bedded limestone; 3 - laminated limestone with shale; 4 - argillaceous limestone; 5 - sandstone and shale; 6 - normal/thrust fault; 7 - buried fault; 8 - town location; 9 - approximate groundwater flow direction; 10 - sampling wells $\bullet$ from deep carbonate aquifers (depth $>80 \mathrm{~m}$ ), $\bigcirc$ from shallow Quaternary aquifer $($ depth $<40 \mathrm{~m}$ ); $11-$ sampling site for seawater.

is known to be associated in some areas with salinisation (e.g. Ghassemi et al., 1995; Kumar et al., 2015) and other groundwater quality issues such as addition of nitrate, sulfate and other compounds contained in fertilisers (e.g. Kaown et al., 2009; Currell et al., 2010). Environmental tracers, such as stable sulfur and carbon isotopes, e.g. $\delta^{34} \mathrm{~S}$ of dissolved $\mathrm{SO}_{4}\left(\delta^{34} \mathrm{~S}_{\mathrm{SO}_{4}}\right)$, and $\delta^{13} \mathrm{C}$ in dissolved inorganic carbon $\left(\delta^{13} \mathrm{C}_{\mathrm{DIC}}\right)$, and major ion chemistry have been useful in identifying sources of salinity and dissolved sulfate and carbonate species in groundwater (Sánchez-Martos et al., 2002; de Montety et al., 2008; Schiavo et al., 2009; Ghiglieri et al., 2012; Kim et al., 2015) and for determining water-rock interaction processes in carbonate aquifers (e.g. carbonate mineral dissolution/precipitation, cation exchange) (Back et al., 1979; Plummer and Sprinkle, 2001; Moral et al., 2008; Daniele et al., 2013). However, to date few areas of major anthropogenic activity and known active or previous salinisation from seawater intrusion have been assessed using these tracers, in order to distinguish different water quality degradation processes, such as seawater-freshwater mixing versus input of agricultural chemicals and irrigation return flow.

This study focuses on the coastal carbonate aquifers around Daweijia well field, which is located in the Daweijia area of Dalian, northeast China. Most previous investigations in this area have focused on the mechanism of seawater intrusion and related water-rock interactions (Wu et al., 1994; Yang, 2011; Zhao et al., 2012), but have ignored the potential impact of anthropogenic contributions to groundwater salinity and water quality degradation. Little is known about the influence of agricultural practices on sulfur cycling and transport in this and other coastal aquifers impacted by intensive agriculture. Here, we report new data for $\mathrm{C}$ and $\mathrm{S}$ isotopes and major ions in groundwater from the Daweijia area, which gives new insight into sources of water quality degradation, including agriculture. Using chemical and isotopic tracers, this study reveals the dominant factors controlling on groundwater hydrochemistry before and after groundwater pumping in the Daweijia well field, and identifies the different sources of sulfate, salinity and determines the major controls on hydrochemical evolution. Understanding these issues can help to prevent further deterioration of groundwater quality in this and other similar systems in north China and elsewhere around the world.

\section{Study area}

The investigated area $\left(39^{\circ} 10^{\prime}-39^{\circ} 14^{\prime} \mathrm{N}\right.$ and $121^{\circ} 37^{\prime}-$ $121^{\circ} 45^{\prime} \mathrm{E}$ ) is located in northeast China along the Bohai Sea coast (Fig. 1). It has a catchment area of $66 \mathrm{~km}^{2}$ to the north of Dalian (population 3.25 million), Liaoning Province. The climate is warm temperate continental monsoon, with an annual average temperature of $\sim 10^{\circ} \mathrm{C}$. Most of the precipitation, totalling $\sim 600 \mathrm{~mm}$ annually (Yang, 2011) falls during the June-September rainy season. The ephemeral Daweijia River runs through the region from east to west. Under natural conditions, groundwater discharged into the sea from the southeast towards the northwest (Fan, 1984). 
The geology of the Daweijia area consists of Quaternary deposits over-lying carbonate aquifers of Paleozoic (Ordovician and Cambrian) and Proterozoic (Sinian) age. Two groups of faults are developed in this area, namely NE normal faults (F1 and F2 in Fig. 1) and EW reverse faults (F3 and F4 in Fig. 1). These structural faults cut the bedrock and are the main channel for groundwater infiltration and movement, affecting the degree of subsurface karst development (Song, 2013). The main karst development sections in the Cambrian and Ordovician formation include (i) 5 to $20 \mathrm{~m}$ a.s.l. (meters above sea level) (near surface karst), (ii) -5 to $-40 \mathrm{~m}$ a.s.l. (shallow karst), (iii) -50 to $-85 \mathrm{~m}$ a.s.l. (medium depth karst), and (iv) <-90 m a.s.l. (deep karst) (Zhao, 1991). The aquifers within the Daweijia area can be divided into upper and lower aquifer systems; the upper aquifer is composed of Quaternary sediments with variable thickness of $0-40 \mathrm{~m}$. This consists of gravel, sand and clay layers and is not extensively pumped for water supply. The carbonate aquifers underlying the Quaternary deposits are mainly composed of Lower Ordovician, Middle and Upper Cambrian limestone, with major karst development in the medium section between -40 and $-70 \mathrm{~m}$ a.s.l. (Lü et al., 1981; Zhao, 1991). The most productive carbonate aquifers are distributed along Daweijia River valley. Figures 1 and 2 show a geological map and stratigraphic cross-section of the hydrogeological system along this valley, showing natural groundwater flow from east to west (Fan, 1984). The geologic contacts and hydraulic connections between the upper and lower aquifer systems used in this study were determined from geologic logs and geophysical exploration during a previous investigation of regional hydrogeology in the Daweijia area (Lü et al., 1981; Jin and Wu, 1990).

Seawater intrusion was first discovered in the Dalian area in 1964. This study focuses on the coastal aquifers around Daweijia well field (Fig. 1), which was established in 1969 and formerly provided major water supply for Dalian at the pumping rates of $12-24 \times 10^{3} \mathrm{~m}^{3} \mathrm{day}^{-1}$ in 1970 (Lü et al., 1981). With the increase of pumping rate till 1983 (up to $4.8-6.2 \times 10^{3} \mathrm{~m}^{3} \mathrm{day}^{-1}$ in 1977), the average chloride concentration of groundwater from eight fixed monitoring wells increased from $380 \mathrm{mg} \mathrm{L}^{-1}$ in 1968 to $1137 \mathrm{mg} \mathrm{L}^{-1}$ in 1982 (Song, 2013), indicating that the serious seawater intrusion occurred. The groundwater withdrawal of the Daweijia well field was changed from a perennial pattern to a seasonal regime with a decrease by two-thirds of the pumped volume. The abstraction increased after 1991 but was reduced again from $20 \times 10^{3} \mathrm{~m}^{3}$ day $^{-1}$ in 1995 to $4 \times 10^{3} \mathrm{~m}^{3}$ day $^{-1}$ in 2000 ( $\mathrm{Li}$ et al., 2006). Alternatively, in order to reduce the threat of seawater intrusion to the aquifer, with the establishment of surface water supply projects, water supply for Dalian from the well field has ceased since 2001, with seasonal pumping for local agricultural irrigation (Song, 2013). The area is also the site of ongoing intensive agricultural activity.
The carbonate aquifer is pumped for agricultural and public water supply. The Daweijia well field was established in 1969 for water supply to Dalian and, at peak usage, the upper aquifer suffered extensive drawdown. Along with this, the average chloride concentration in groundwater increased from $199 \mathrm{mg} \mathrm{L}^{-1}$ in 1966 to $559 \mathrm{mg} \mathrm{L}^{-1}$ in 1991 , and reached a peak of $940 \mathrm{mg} \mathrm{L}^{-1}$ in 1994 . Under the restrictions on groundwater extraction enacted, the $\mathrm{Cl}$ value returned to $454 \mathrm{mg} \mathrm{L}^{-1}$ in 2005 . This included the drastic measure of switching off the well field supplying Dalian since 2001 (Song, 2013). Although the groundwater levels have recovered in recent years, groundwater salinity has not completely been reversed, and elevated nitrate and sulfate concentrations have continued since this time. Potential causes include "residual" seawater intrusion which has not yet re-equilibrated with recovered water levels and/or different sources of contamination, associated with agriculture or urban activities.

\section{Methods}

\subsection{Sampling and analysis}

We collected 30 water samples during two sampling campaigns (June 2006 and August 2010) for analysis of major ions and stable isotopes $\left(\delta^{13} \mathrm{C}_{\text {DIC }}\right.$ and $\left.\delta^{34} \mathrm{~S}_{\mathrm{SO}_{4}}\right)$. The samples include 29 from wells and one seawater sample. Sampling wells are production wells with variable depths $(8.4-128 \mathrm{~m})$ and screened intervals (lengths of 2-35 m; see Table 1) and these are distributed mainly along the Daweijia River valley (Fig. 1). The screened intervals of wells in the carbonate aquifer are mainly between 65 and $100 \mathrm{~m}$ below ground surface (Table 1). Before sampling, the wells were pumped for at least for half an hour until physico-chemical parameters (e.g. water temperature, $\mathrm{pH}$, electrical conductivity and dissolved oxygen) stabilised. All samples were filtered through $0.45 \mu \mathrm{m}$ pore-size filter paper and stored in HDPE bottles at $4{ }^{\circ} \mathrm{C}$ in a cool room until analysis. The samples prepared for cation analysis were acidified to $\mathrm{pH}<2$ by adding high purity $\mathrm{HNO}_{3}$. Bicarbonate was determined in the field by titrating with $0.22 \mathrm{~N} \mathrm{H}_{2} \mathrm{SO}_{4}$. Major anions were measured by ion chromatography (SHIMADZU), and major cations were determined using ICP-AES by the Laboratory of Physics and Chemistry, Institute of Geographic Sciences and Natural Resources Research (IGSNRR), Chinese Academy of Sciences (CAS). The ion balance errors of the chemical analyses were generally within $\pm 15 \%$. The PHREEQC-2 hydrogeochemical code (version 2.18.3, Parkhurst and Appelo, 1999) was used to determine the saturation indexes (SI) of calcite, dolomite and gypsum.

The $\delta^{13} \mathrm{C}$ values of dissolved inorganic carbon (DIC) in 16 water samples were measured using continuous flow on a Finnigan MAT 252 mass spectrometer, with the automated headspace analysis of the preparation device, in the State 


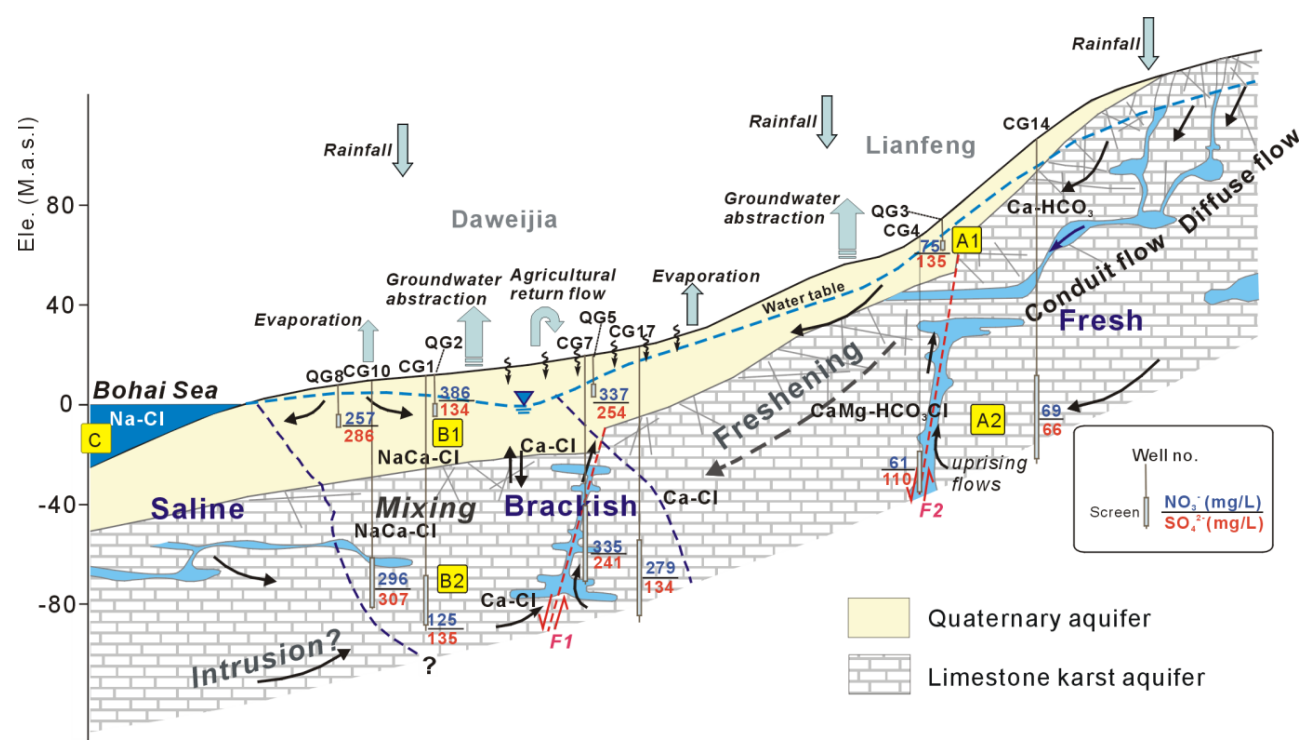

Figure 2. Conceptual model showing the hydrogeological system (modified after Yang, 2011) and $\mathrm{NO}_{3}^{-}$and $\mathrm{SO}_{4}^{2-}$ concentrations and sources. Characteristic ranges of $\delta^{13} \mathrm{C}$ and $\delta^{34} \mathrm{~S}_{\mathrm{SO}_{4}}$ values for $\mathrm{A} 1, \mathrm{~A} 2, \mathrm{~B} 1, \mathrm{~B} 2$ and $\mathrm{C}$ are shown in Table 3. Arrows in aquifers indicate general groundwater flow direction.

Key Laboratory of Environmental Geochemistry, Institute of Geochemistry (Guiyang), CAS. The results of $\delta^{13} \mathrm{C}$ analysis are expressed in conventional delta $(\delta)$ notation, defined as $\delta=\left(R_{\text {sample }}-R_{\text {standard }}\right) / R_{\text {standard }} \times 1000$, where $R$ is the ratio of ${ }^{13} \mathrm{C} /{ }^{12} \mathrm{C}$. The $\delta^{13} \mathrm{C}$ values of dissolved inorganic carbon (DIC) are expressed relative to the standard Vienna Peedee Belemnite (VPDB), with an analytical precision of $\pm 0.2 \%$. Samples for ${ }^{34} \mathrm{~S}$ in dissolved sulfate in 18 groundwater samples (Table 1) were measured by a Finnigan MAT Delta-S gas mass spectrometer after online pyrolysis with an EA (elemental analyser) in the Laboratory for Stable Isotope Geochemistry, Institute of Geology and Geographysics, CAS. The method of Halas and Szaran (1999) was used for converting precipitated $\mathrm{BaSO}_{4}$ to $\mathrm{SO}_{2}$. The international standard against which $\delta^{34} \mathrm{~S}$ values are referenced is the troilite (FeS) phase of the Cañon Diablo meteorite (CDT), which has a ${ }^{34} \mathrm{~S} /{ }^{32} \mathrm{~S}$ abundance ratio of 0.0450 and are reported as $\delta(\%)$ difference from the standard with an analytical precision of better than or about $\pm 0.4 \%$.

\subsection{Ionic deltas and mixing calculations}

To further investigate the hydrochemical behaviour of major cations and diagnose the processes modifying hydrochemical composition of groundwater in the aquifer, ionic delta values were calculated. The delta values express enrichment or depletion of particular ions relative to a conservative mixing system. These have been used in previous studies as effective indicators of groundwater undergoing freshening or salinisation, along with associated water-rock interaction processes (primarily cation exchange - e.g. Appelo, 1994). Based on variations of molar $\mathrm{Cl} / \mathrm{Br}$ ratios and major ions in ground- water (Sect. 5.1), we have ruled out significant sources of $\mathrm{Cl}^{-}$other than meteoric and oceanic inputs. It is assumed in these calculations that there is no chloride input from salts in the aquifer matrix itself, and that $\mathrm{Cl}$ can be regarded as the most conservative species during mixing and hydrochemical evolution. The fraction of seawater $\left(f_{\text {sea }}\right)$ in a groundwater sample can thus be calculated using (Appelo and Postma, 2005)

$f_{\mathrm{sw}}=\frac{C_{\mathrm{Cl}, \mathrm{sam}}-C_{\mathrm{Cl}, \mathrm{f}}}{C_{\mathrm{Cl}, \mathrm{sw}}-C_{\mathrm{Cl}, \mathrm{f}}}$,

where $C_{\mathrm{Cl} \text {,sam }}, C_{\mathrm{Cl} \text {,fresh }}$, and $C_{\mathrm{Cl}, \text { sw }}$ refer to the $\mathrm{Cl}$ concentration in the sample, freshwater, and seawater, respectively.

The theoretical concentration $\left(C_{i, \text { mix }}\right)$ of an ion $i$ in a water sample can be calculated by comparing the measured concentration of this ion with its expected composition from conservative mixing between seawater and freshwater (Appelo and Postma, 2005):

$C_{i, \text { mix }}=f_{\mathrm{sw}} \cdot C_{i, \mathrm{sw}}+\left(1-f_{\mathrm{sw}}\right) \cdot C_{i, \mathrm{f}}$,

where $C_{i, \text { sam }}$ and $C_{i, \mathrm{f}}$ - the measured concentration of the ion $i$ in the water sample and freshwater, respectively; $f_{\mathrm{sw}}-$ fraction of seawater. The ionic deltas $\left(\Delta C_{i}\right)$ of ion $i$ can thus be obtained by:

$\Delta C_{i}=C_{i, \mathrm{sam}}-C_{i, \mathrm{mix}}$. 


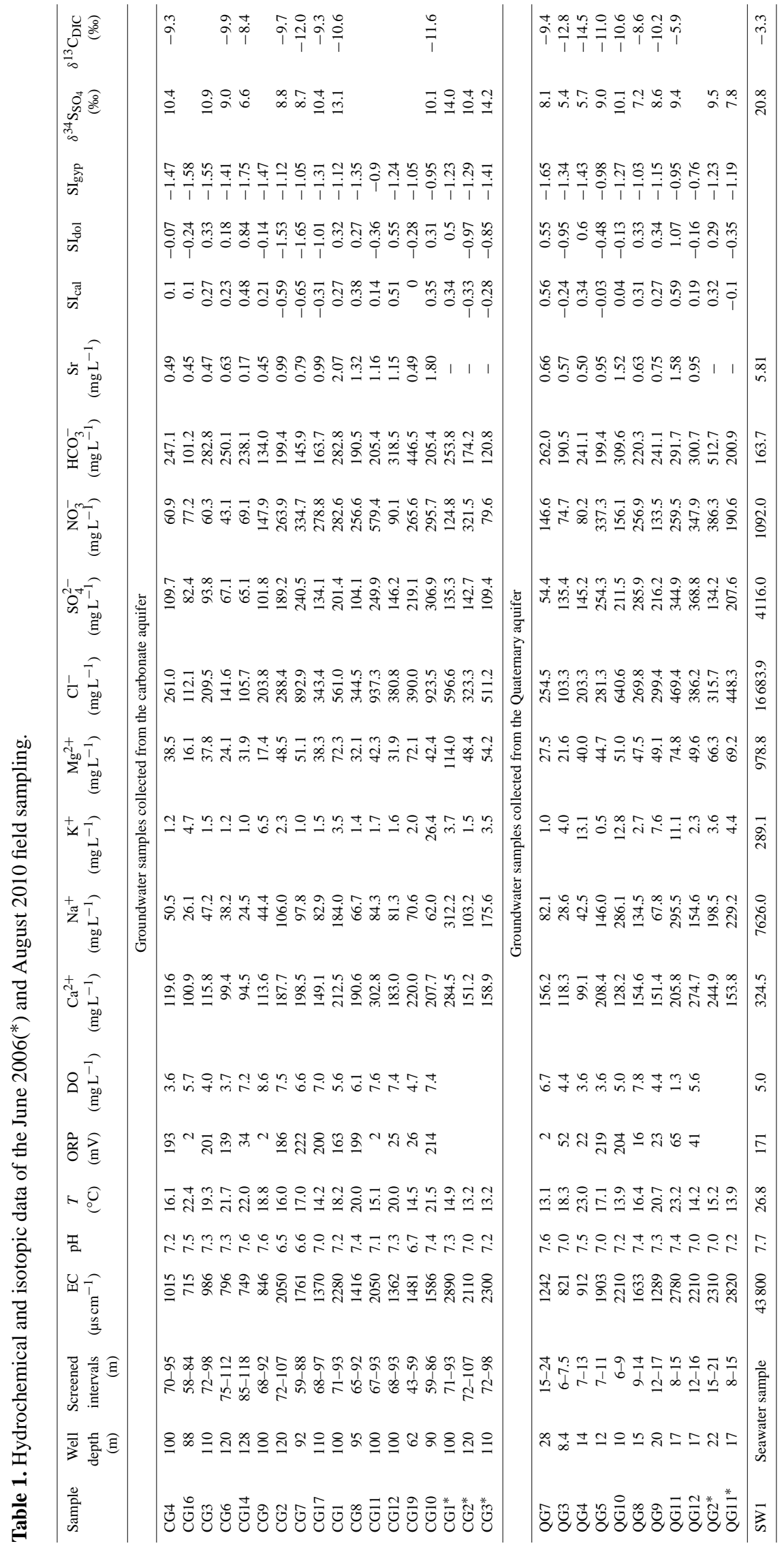



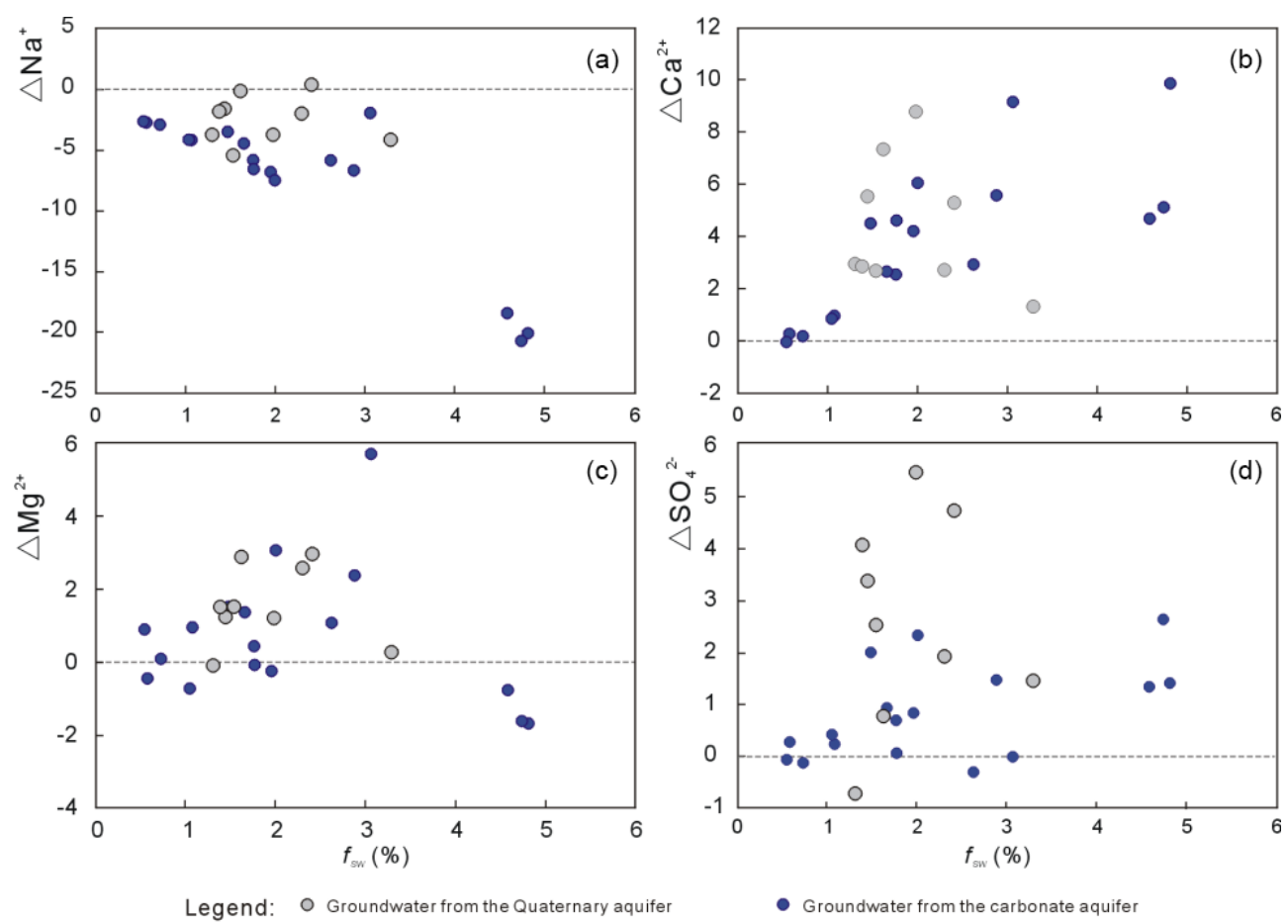

Figure 3. Graphs showing the cationic $\Delta$ values of groundwater samples vs. fraction of seawater: (a) $\Delta \mathrm{Na}^{+}$, (b) $\Delta \mathrm{Ca}^{2+}$, (c) $\Delta \mathrm{Mg}^{2+}$, and (d) $\Delta \mathrm{SO}_{4}^{2-}$.

\section{Results}

\subsection{Chemical analysis}

The physical and chemical characteristics of groundwater samples from the Quaternary aquifer (QA) and the Cambrian-Ordovician carbonate aquifer (COA) in the Daweijia are compiled in Table 1. Total dissolved solids (TDS) concentrations vary from 372 to $2403 \mathrm{mg} \mathrm{L}^{-1}$, with values increasing along the main direction of groundwater flow from the east towards the sea. Groundwater $\mathrm{pH}$ ranges from 6.5 to 7.6, with a mean of 7.2. Dissolved oxygen concentrations range from 1.3 to $8.6 \mathrm{mg} \mathrm{L}^{-1}$ with a mean of $5.6 \mathrm{mg} \mathrm{L}^{-1}$. The fresh $\left(<1 \mathrm{~g} \mathrm{~L}^{-1} \mathrm{TDS}\right)$ groundwater (e.g. CG6, CG14) is characterised as $\mathrm{Ca}-\mathrm{HCO}_{3}(\cdot \mathrm{Cl})$ type water, while brackish (1 to $10 \mathrm{gL}^{-1} \mathrm{TDS}$ ) groundwater (e.g. CG7, CG10, CG11, CG17) is predominantly $\mathrm{Ca}-\mathrm{Cl}$ type in the carbonate aquifer. Brackish groundwater in the shallow Quaternary aquifer was observed to be $\mathrm{Ca}-\mathrm{Cl} \cdot \mathrm{SO}_{4}$ type water, or near the coastline (e.g. QG10, QG11), Na.Ca$\mathrm{Cl}\left(\cdot \mathrm{HCO}_{3}\right)$ type.

According to mixing calculations, minor seawater intrusion near the coastline is identified (Fig. 3), however the fraction of seawater does not exceed $5 \%$ and this compares with a fraction of $20.8 \%$ observed in 1982 (Wu et al., 1994). The groundwater in this study is characterised by a wide range of sulfate concentrations between 54.4 and $368.8 \mathrm{mg} \mathrm{L}^{-1}$, with a mean value of $174.4 \mathrm{mg} \mathrm{L}^{-1}$. Nitrate concentrations ranged from 43.1 to $579.4 \mathrm{mg} \mathrm{L}^{-1}$, with a mean value of $206.9 \mathrm{mg} \mathrm{L}^{-1}$, far beyond the drinking water standard $\left(50 \mathrm{mg} \mathrm{L}^{-1}\right)$ in China. The investigated seawater sample also has a very high nitrate concentration of $1092 \mathrm{mg} \mathrm{L}^{-1}$.

Comparing background data (1962, Lü et al., 1981) and current data (2010, in this study), the nitrate concentrations in groundwater increased from a range of $0-10.9 \mathrm{mg} \mathrm{L}^{-1}$ ( $n=51$, mean value of $2.1 \mathrm{mg} \mathrm{L}^{-1}$ ) in 1962 to a range of $43.1-579.4 \mathrm{mg} \mathrm{L}^{-1}\left(n=15\right.$, mean value of $\left.207.1 \mathrm{mg} \mathrm{L}^{-1}\right)$ in 2010 in the carbonate aquifer, and mean sulfate concentration increased from a range of $0-121.6 \mathrm{mg} \mathrm{L}^{-1}(n=64$, mean value of $72.4 \mathrm{mg} \mathrm{L}^{-1}$ ) in 1962 to a range of $65.1-$ $306.9 \mathrm{mg} \mathrm{L}^{-1}\left(n=15\right.$, mean value of $\left.154.1 \mathrm{mg} \mathrm{L}^{-1}\right)$ in 2010 . For the Quaternary aquifer, nitrate concentrations have changed from a range of $0-9.9 \mathrm{mg} \mathrm{L}^{-1}(n=3$, mean value of $\left.6.7 \mathrm{mg} \mathrm{L}^{-1}\right)$ in 1962 to a range of $74.7-347.9 \mathrm{mg} \mathrm{L}^{-1}(n=9$, mean value of $199.2 \mathrm{mg} \mathrm{L}^{-1}$ ) in 2010 , and sulfate from a range of $0-64.1 \mathrm{mg} \mathrm{L}^{-1}\left(n=3\right.$, mean value of $\left.35.2 \mathrm{mg} \mathrm{L}^{-1}\right)$ in 1962 to a range of $54.4-368.8 \mathrm{mg} \mathrm{L}^{-1}(n=9$, mean value of $224.1 \mathrm{mg} \mathrm{L}^{-1}$ ) in 2010 .

The ionic delta values are plotted in Fig. 3, illustrating the varied distribution of geochemical types and evolution in the aquifer. Generally most groundwater samples are characterised by negative $\Delta \mathrm{Na}^{+}$values and positive $\Delta \mathrm{Ca}^{2+}$ values. Some brackish groundwater samples have negative $\Delta \mathrm{Na}^{+}$ values and positive $\Delta \mathrm{Ca}^{2+}+\Delta \mathrm{Mg}^{2+}$ values, displaying 

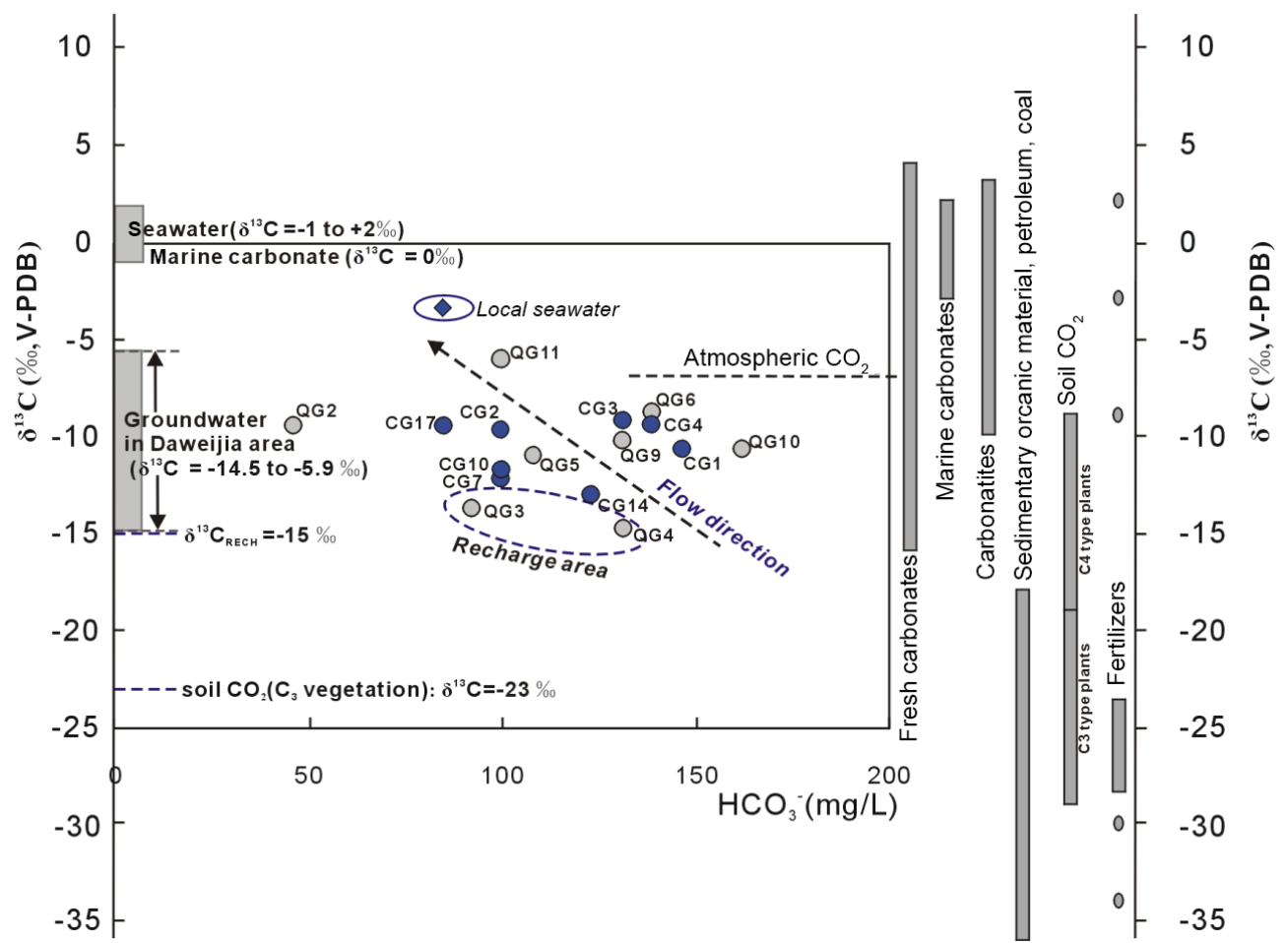

Figure 4. $\delta^{13} \mathrm{C}_{\mathrm{DIC}}$ vs. dissolved inorganic carbon for the groundwater samples (August 2009) in the Daweijia area, comparing with $\delta^{13} \mathrm{C}$ values for the main carbon reservoirs (Vitòria et al. (2004) and therein). See Fig. 3 for legend.

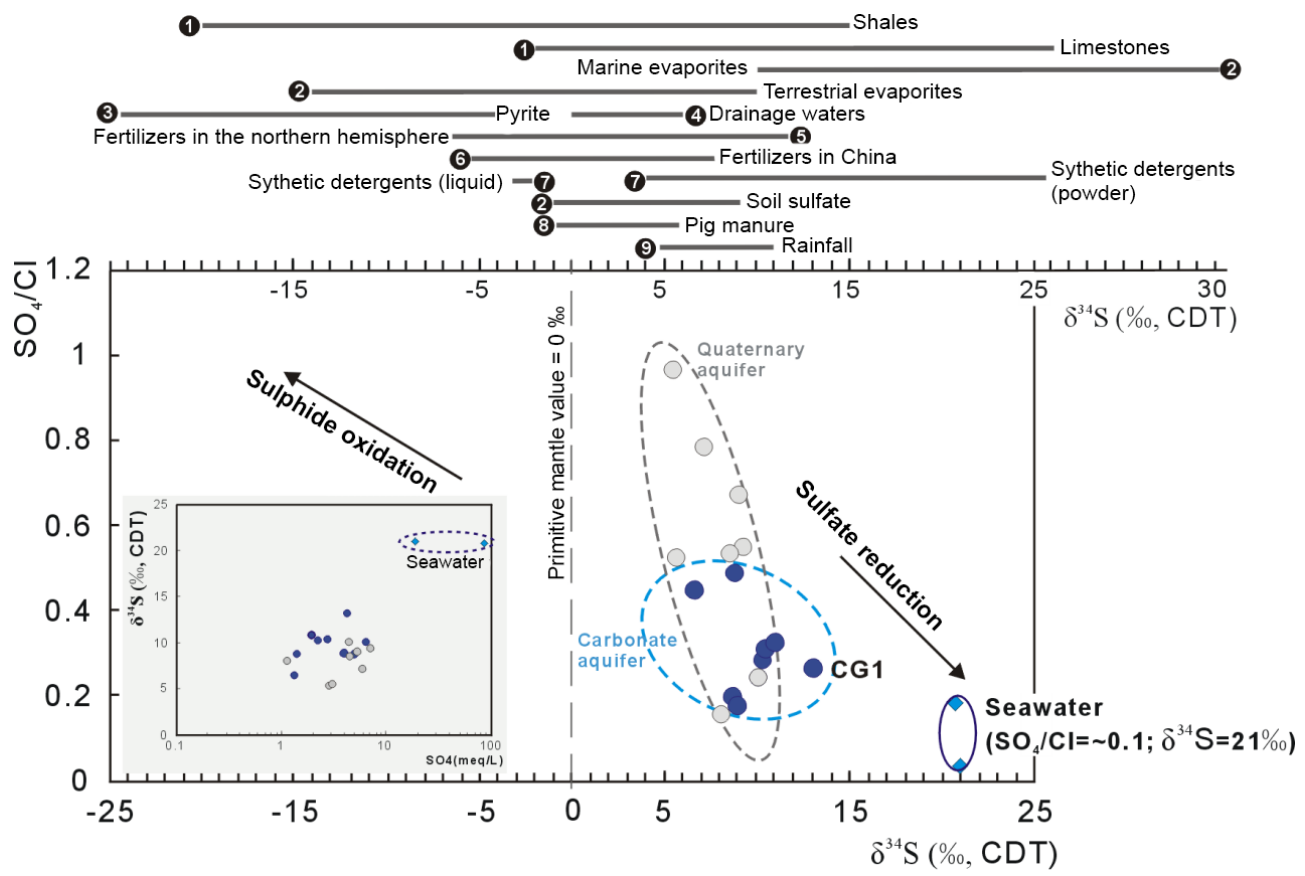

Figure 5. ${ }^{34} \mathrm{~S}$ of dissolved $\mathrm{SO}_{4}$ versus $\mathrm{SO}_{4} / \mathrm{Cl}$ for groundwater samples from the Daweijia area. The range of sulfur isotopic values of some major sulfur reservoirs and selected materials is summarised from literature compiled data as follows: 1 - Clark and Fritz (1997); 2 Vitòria et al. (2004); 3 - Szynkiewicz et al. (2012); 4 - Unland et al. (2012); 5 - Szynkiewicz et al. (2011); 6 - Li et al. (2006); 7 - Hosono et al. (2007); 8 - Cravotta (1995) and Otero et al. (2007); 9 - Hong et al. (1994). See Fig. 3 for legend. 
a deficit of $\mathrm{Na}^{+}$with a corresponding excess in $\mathrm{Ca}^{2+}$ and $\mathrm{Mg}^{2+}$. There are positive values of $\Delta \mathrm{SO}_{4}^{2-}$ observed in most groundwater sample, and these are particularly high in the brackish groundwater (Fig. 3d).

\subsection{Dissolved inorganic carbon (DIC) and $\delta^{13} \mathrm{C}_{\text {DIC }}$}

Figure 4 presents the $\delta^{13} \mathrm{C}_{\mathrm{DIC}}$ isotope data and this can be used to infer the sources and evolution of dissolved inorganic carbon in the investigated groundwater (Clark and Fritz, 1997). The measured $\delta^{13} \mathrm{C}_{\text {DIC }}$ values in groundwater range from -14.5 to $-5.9 \%$ vs. $\mathrm{PDB}$, with a mean value of $-10.5 \%$ (Table 1 ). The water samples from the carbonate aquifer show a relatively narrow range of $\delta^{13} \mathrm{C}_{\mathrm{DIC}}$ values $(-12$ to $-8.4 \%$ with a mean value of $-10.1 \%, n=8)$ comparable to the range of $\delta^{13} \mathrm{C}_{\mathrm{DIC}}$ values $(-14.5$ to $-5.9 \%$, mean of $-10.0 \%, n=7$ ) from the Quaternary aquifer. The waters collected in the upstream areas show $\delta^{13} \mathrm{C}$ values from -14.5 to $-12.8 \%$, while the middle area has values of -12.0 to $-9.0 \%$ and the coastline values between -10.6 and $-5.9 \%$ (Fig. 4, Table 1).

The local seawater sample (SW1) has a $\delta^{13} \mathrm{C}_{\mathrm{DIC}}$ value of $-3.3 \%$, which is relatively low compared to other reported values of modern seawater ( -1 to $+2 \%$, Clark and Fritz, 1997). Carbon in $C_{4}$ plants, which include maize, sugar cane and sorghum, has $\delta^{13} \mathrm{C}$ values that range from -10 to $-16 \%$ with a mean value of $\sim-12.5 \%$, while most $\mathrm{C}_{3}$ plants have $\delta^{13} \mathrm{C}$ values that range from -24 to $-30 \%$, with an average of $\sim-27 \%$ (Vogel, 1993). Maize is the main agricultural product in the study area $(\mathrm{Hu}, 2010)$, indicating that a $\mathrm{C}_{4}$ vegetation source may be dominant. Carbonate dissolution and/or exchange leads to progressive enrichment of $\delta^{13} \mathrm{C}$ values towards the values of the mineral, usually with values between -2 and $+2 \%$.

\subsection{Stable isotopes of sulfate}

The $\delta^{34} \mathrm{~S}_{\mathrm{SO}_{4}}$ compositions varied between +5.4 and $+13.1 \%$ (Table 1). Sample CG1, with a sampling depth of $100 \mathrm{~m}$ and collected from the centre of a residential area, has the highest $\delta^{34} \mathrm{~S}_{\mathrm{SO}_{4}}$ value $\left(+13.1 \%\right.$ ). The lowest $\delta^{34} \mathrm{~S}_{\mathrm{SO}_{4}}$ value $(+5.4 \%$ o $)$ was found for sample QG3 collected in an upstream area. Water samples from the carbonate aquifer are denoted with dashed line in Fig. 5 and have relatively high $\delta^{34} \mathrm{~S}_{\mathrm{SO}_{4}}$ values (ranging from +6.6 to $+13.1 \%$ with a mean value of $+9.9 \%, n=9)$ and low $\mathrm{SO}_{4} / \mathrm{Cl}$ ratios. The groundwater samples from the Quaternary aquifer are characterised by a relatively narrow range of $\delta^{34} \mathrm{~S}_{\mathrm{SO}_{4}}$ values (ranging from +5.4 to $+10.1 \%$ with a mean value of $+7.9 \%, n=8)$ and a wider range of $\mathrm{SO}_{4} / \mathrm{Cl}$ ratios. Some brackish groundwater (QG2 and QG10) from the Quaternary aquifer also shows these characteristics (Fig. 5). In general, the $\delta^{34} \mathrm{~S}_{\mathrm{SO}_{4}}$ values increase with correspondingly lower $\mathrm{SO}_{4} / \mathrm{Cl}$ ratios in the direction of the coastline.

\section{Discussion}

A number of geochemical processes control the evolution of groundwater in the study area. Some of these processes show evidence of taking place in both carbonate and Quaternary aquifers, while others are more confined to one of the aquifers. The major hydrochemical processes inferred from the data are summarised in Table 2, which also includes a description of lines of evidence used to infer these (in most cases two supporting lines of evidence exist).

\subsection{Seawater intrusion, freshening and cation exchange}

Widespread seawater intrusion appears to be a thing of the past, although local salinisation continues around the well field. Chloride is an important index for estimating the extent of seawater intrusion, and is generally assumed to behave relatively conservatively. The molar $\mathrm{Cl} / \mathrm{Br}$ ratios (based on values from this study and Yang et al., 2011) range from 118.3 to 633.1 ( $n=11$, mean value 394.3 ), which is generally below the oceanic ratio of $\sim 650$ (Drever, 1997). As halite is $\mathrm{Br}$-depleted from its mineral structure, halite precipitation may lead to depletion of the ratios, however it is unlikely that saturation with respect to halite could be reached in the groundwater (e.g. McCaffrey et al., 1987; Edmunds, 1996; Cartwright et al., 2004). Minor contamination, e.g. with pesticides such as ethyl dibromine, methyl bromide and/or preferential $\mathrm{Cl}$ adsorption on organic material may explain the lower than usual ratios. Overall the ratios do not indicate significant sources of additional $\mathrm{Cl}$. The TDS concentrations of groundwater in this study area varied within a range of 0.4$4.5 \mathrm{~g} \mathrm{~L}^{-1}$ in 1981 (the peak period of seawater intrusion) (Lü et al., 1981). For the well CG2 located in the centre of the well field, TDS was $0.3 \mathrm{~g} \mathrm{~L}^{-1}$ on December $1965,0.71 \mathrm{~g} \mathrm{~L}^{-1}$ on August 1981, $0.66 \mathrm{~g} \mathrm{~L}^{-1}$ on December 1981, and up to $1.19 \mathrm{~g} \mathrm{~L}^{-1}$ on August 2010, an obvious increasing trend, however, $\mathrm{Cl}^{-}$concentrations decreased from $375.6 \mathrm{mg} \mathrm{L}^{-1}$ in August 1981 to $288.4 \mathrm{mg} \mathrm{L}^{-1}$ in August 2010. By contrast, there are much more significant increases on $\mathrm{SO}_{4}^{2-}$ and $\mathrm{NO}_{3}^{-}$concentrations in groundwater, which explains increasing TDS but decreasing chloride. For the well $\mathrm{CG} 2, \mathrm{SO}_{4}^{2-}$ concentration increased 5 times from $38.2 \mathrm{mg} \mathrm{L}^{-1}$ in August 1981 to $189.2 \mathrm{mg} \mathrm{L}^{-1}$ in August 2010. While $\mathrm{NO}_{3}^{-}$concentration increased 4 times from $64.6 \mathrm{mg} \mathrm{L}^{-1}$ in August 1981 to $263.9 \mathrm{mg} \mathrm{L}^{-1}$ in August 2010 - far higher than the overall changes in TDS. These changes in different ion concentrations in groundwater show that the anthropogenic input (e.g. application of agricultural fertiliser) has modified the hydrochemical composition of groundwater to a great extent after the cessation of pumping in the well field.

The freshening of coastal aquifers can be shown using the multi-rectangular HFE diagram (Fig. 6). This classification method proposed by Giménez-Forcada (2010) can be employed to determine the dynamics of seawater intrusion, considering the percentages of major ions, showing the intrud- 
Table 2. Summary of main hydrochemical processes occurring in the carbonate and Quaternary aquifer, along with evidence used to assess the process.

\begin{tabular}{|c|c|c|c|c|c|}
\hline $\begin{array}{l}\text { Aquifer } \\
\text { (Carb/Quat) }\end{array}$ & Process & $\begin{array}{l}\text { Occurring } \\
(\mathrm{Y} / \mathrm{N}) ?\end{array}$ & Evidence (1) & Evidence (2) & Figure \\
\hline \multirow{5}{*}{ Carbonate aquifer } & $\begin{array}{l}\text { Calcite dissolution } \\
\text { (congruent) }\end{array}$ & $\begin{array}{l}\text { No } \\
\text { and } \mathrm{Ca}: \mathrm{HCO}_{3}>1: 2\end{array}$ & $\begin{array}{l}\text { Most groundwater } \\
\text { samples with } \mathrm{SI}_{\text {calcite }}<0.1 \\
\mathrm{HCO}_{3} \text { and } \delta^{13} \mathrm{C}\end{array}$ & $\begin{array}{l}\text { No correlation } \\
\text { between } \mathrm{Ca} \text { and } \delta^{13} \mathrm{C}\end{array}$ & Fig. 7 \\
\hline & $\begin{array}{l}\text { Incongruent } \\
\text { dolomite } \\
\text { weathering }\end{array}$ & Yes & $\begin{array}{l}\text { Increase in } \mathrm{Mg} / \mathrm{Ca} \text { along } \\
\text { the flow path }\end{array}$ & $\begin{array}{l}\text { Increase in } \delta^{13} \mathrm{C} \\
\text { with increasing } \\
\mathrm{Mg} / \mathrm{Ca}\end{array}$ & Fig. $7 \mathrm{a}$ \\
\hline & Cation exchange & Yes & $\begin{array}{l}\text { Most samples with } \\
\text { negative } \Delta \mathrm{Na}^{+} \text {values } \\
\text { and positive } \Delta \mathrm{Ca}^{2+}+ \\
\Delta \mathrm{Mg}^{2+} \text { values }\end{array}$ & $\begin{array}{l}\text { MixCa-Cl facies in } \\
\text { HFE diagram }\end{array}$ & Figs. 3 and 6 \\
\hline & Fertiliser addition & Yes & $\begin{array}{l}\text { Positive correlation } \\
\text { between } \mathrm{NO}_{3}^{-} \text {and } \mathrm{SO}_{4}^{2-} \\
\text { concentrations }\end{array}$ & $\begin{array}{l}\text { Mass balance } \\
\text { results from } \\
\text { different sources } \\
\text { of } \delta^{34} \mathrm{~S}_{\mathrm{SO}_{4}} \\
\end{array}$ & Figs. 9 and 10 \\
\hline & Gypsum dissolution & Yes & $\begin{array}{l}\text { All water samples with } \\
\text { SI }_{\text {gypsum }}<-0.5\end{array}$ & $\mathrm{Ca} / \mathrm{SO}_{4}$ ratios $>1$ & - \\
\hline \multirow{5}{*}{ Quaternary aquifer } & $\begin{array}{l}\text { Calcite dissolution } \\
\text { (congruent) }\end{array}$ & Minor & $\begin{array}{l}\text { Lack of correlation } \\
\text { between } \delta^{13} \mathrm{C} \text { and } \\
\mathrm{HCO}_{3} ; \text { increasing } \delta^{13} \mathrm{C} \\
\text { with increasing Ca }\end{array}$ & $\begin{array}{l}\text { Most groundwater } \\
\text { samples with } \\
\mathrm{SI}_{\text {calcite }}<0.1 \text { and } \\
\mathrm{Ca}: \mathrm{HCO}_{3} \text { around } 1: 2\end{array}$ & Fig. 7 \\
\hline & $\begin{array}{l}\text { Incongruent } \\
\text { dolomite } \\
\text { weathering }\end{array}$ & $\begin{array}{l}\text { No } \\
\text { (apart from } \\
\text { QG3) }\end{array}$ & $\begin{array}{l}\mathrm{SI}_{\text {dolomite }}>-0.5 \\
\mathrm{Mg}: \mathrm{HCO}_{3}>1: 4\end{array}$ & $\begin{array}{l}\text { No obvious } \\
\text { increasing trend in } \\
\delta^{13} \mathrm{C} \text { with } \\
\text { increasing } \mathrm{Mg} / \mathrm{Ca}\end{array}$ & Fig. 7 \\
\hline & Cation exchange & Yes & $\begin{array}{l}\text { Enrichment in } \mathrm{Ca} \text { and } \\
\text { loss of } \mathrm{Na} \text { along flow } \\
\text { path }\end{array}$ & $\begin{array}{l}\mathrm{SI}_{\text {calcite }} \text { and } \mathrm{SI}_{\text {dolomite }} \\
\text { close to or } \\
\text { exceeding } 0\end{array}$ & Fig. 3 \\
\hline & $\begin{array}{l}\text { Addition of sulfate } \\
\text { from fertiliser }\end{array}$ & Yes & $\begin{array}{l}\text { Positive relationship } \\
\text { between } \mathrm{SO}_{4} \text { and } \mathrm{NO}_{3}\end{array}$ & $\begin{array}{l}\text { Increasing } \delta^{34} \mathrm{~S} \\
\text { values with } \\
\text { increasing } \mathrm{NO}_{3} \\
\text { concentrations }\end{array}$ & Figs. 9 and 10 \\
\hline & Gypsum dissolution & Yes & $\mathrm{Ca}: \mathrm{SO}_{4}$ close to 1 & $\mathrm{SI}_{\text {gyp }}<-0.5$ & - \\
\hline
\end{tabular}

ing and freshening phases in hydrochemical facies evolution. The freshwater in the recharge area mainly belongs to the $\mathrm{Ca}-\mathrm{MixHCO}_{3}$ (14) facies, and seawater belongs to the $\mathrm{Na}-$ $\mathrm{Cl}$ (4) facies. Most of the groundwater samples do not follow the predicted succession of facies along the mixing line (47-10-13), and rather indicate a small degree of simple mixing between freshwater and seawater components, along with inverse cationic exchange between $\mathrm{Na}$ and $\mathrm{Ca}$. This leads to the water reaching the $\mathrm{Ca}-\mathrm{Cl}$ (16) facies observed in brackish groundwater in the carbonate aquifer. The surplus $\mathrm{Ca}^{2+}$ from ion exchange may also cause super-saturation with respect to calcite and dolomite, consistent with the observed positive values in the majority of samples (Langmuir, 1971). Net dissolution of carbonate minerals is not evident as a major process in the groundwater, as is shown by a number of lines of evidence below ( $\mathrm{Mg}$ / Ca ratios, stable isotopes of DIC - see Table 2). Cation exchange is thus considered crucial to the development of the $\mathrm{Ca}-\mathrm{Cl}$ facies in the more evolved waters.

Generally most groundwater samples collected from west of the Daweijia well field are characterised by depletion of $\mathrm{Na}^{+}$more or less balanced by equivalent enrichment of $\mathrm{Mg}^{2+}$ plus $\mathrm{Ca}^{2+}$. Both $\Delta \mathrm{Na}^{+}$and $\Delta \mathrm{Mg}^{2+}$ decrease with an increasing fraction of seawater $\left(f_{\mathrm{sw}}\right)$, especially for $f_{\mathrm{sw}}>3 \%$ (Fig. 3), which would be more characteristic of a salinisationdriven base exchange process (Appelo and Postma, 2005). This may suggest a residual effect from the previous saline intrusion which is yet to re-equilibrate with the aquifer matrix. Most groundwater samples from the carbonate aquifer show $\Delta \mathrm{Ca}^{2+}, \Delta \mathrm{Mg}^{2+}$, and $\Delta \mathrm{SO}_{4}^{2-}$ increases with salinity, 


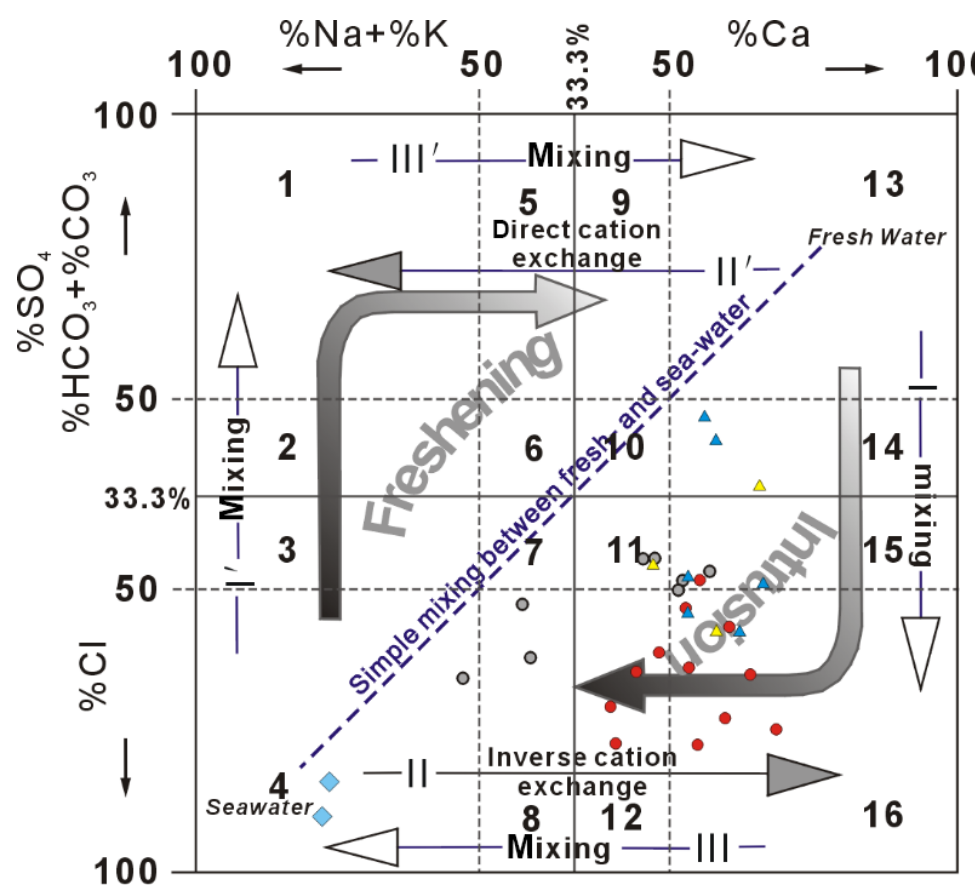

Facies:

1. $\mathrm{Na}-\mathrm{HCO}_{3}$

2. $\mathrm{Na}-\mathrm{MixHCO}_{3}$

3. $\mathrm{Na}-\mathrm{MixCl}$

4. $\mathrm{Na}-\mathrm{Cl}$

5. $\mathrm{MixNa}-\mathrm{HCO}_{3}$

6. $\mathrm{MixNa}-\mathrm{MixHCO}_{3}$

7. Mix Na-MixCl

8. $\mathrm{MixNa}-\mathrm{Cl}$

9. $\mathrm{MixCa}-\mathrm{HCO}_{3}$

10. MixCa-MixHCO

11. MixCa-MixCl

12. $\mathrm{MixCa}-\mathrm{Cl}$

13. $\mathrm{Ca}-\mathrm{HCO}_{3}$

14. $\mathrm{Ca}-\mathrm{MixHCO}$

15. $\mathrm{Ca}-\mathrm{MixCl}$

16. $\mathrm{Ca}-\mathrm{Cl}$

Legend:

$\triangle \quad$ Fresh gw in QA

- Brackish gw in QA

Fresh gw in COA

- Brackish gw in COA

Bohai seawater

Figure 6. Hydrogeochemical facies evolution (HFE) diagram. QA - Quaternary aquifer; COA - Cambrian-Ordovician carbonate aquifer.

whereas $\Delta \mathrm{Na}^{+}$decreases as salinity increases (Fig. 3), consistent with inverse cation exchange.

For fresh groundwater in the carbonate aquifer, the ionic deltas values are close to 0 , indicating the modifying processes are controlled by conservative mixing and there has been little chemical interaction between the groundwater and the aquifer material. Compared to the conservative mixing, the excess of $\mathrm{SO}_{4}$ observed (positive $\Delta \mathrm{SO}_{4}^{2-}$ values) might be attributed to gypsum dissolution, under the influence of seawater intrusion (creating temporary undersaturation). However, only greater degrees of seawater intrusion can cause gypsum dissolution to result in the $\mathrm{SO}_{4}$ excess (Daniele et al., 2013), and the chloride data are inconsistent with ongoing seawater intrusion. It can therefore be inferred that there must be an additional source of $\mathrm{SO}_{4}$. Anthropogenic fertiliser input may explain the increases in $\mathrm{SO}_{4}^{2-}$ along with $\mathrm{NO}_{3}^{-}$and possibly even $\mathrm{Ca}^{2+}$ and $\mathrm{Cl}^{-}$in the aquifer, as is discussed further below.

\subsection{Groundwater interaction with carbonate minerals}

The evolution of DIC and $\delta^{13} \mathrm{C}_{\mathrm{DIC}}$ in the carbonate system begins with atmospheric $\mathrm{CO}_{2}$ with $\delta^{13} \mathrm{C}$ value $\sim-7 \%$ VPDB, while subsequent dissolution of soil gas carbon dioxide leads to depletion of the carbon, depending on which source of vegetation is dominant (Clark and Fritz, 1997). Concentrations of DIC in fresh and brackish groundwater were in the range of $60.1-446.5 \mathrm{~m} \mathrm{~L}^{-1}$ (average $189.2 \mathrm{mg} \mathrm{L}^{-1}$ ) and $46.2-512.7 \mathrm{mg} \mathrm{L}^{-1}$ (average $203.1 \mathrm{mg} \mathrm{L}^{-1}$ ), respectively (Table 1 ). The $\delta^{13} \mathrm{C}_{\text {DIC }}$ values of groundwater ranging from -14.5 to $-5.9 \%$ vs. PDB are similar to groundwater from carbonate aquifers in southwest China, which has typical values ranging from -15.0 to $-8.0 \%$ ( $\mathrm{Li}$ et al., 2010). The $\delta^{13} \mathrm{C}_{\mathrm{DIC}}$ in groundwater shows a negative correlation with DIC concentration, particularly in the karst aquifer (Fig. 4). This indicates that simple, congruent dissolution of carbonate minerals is not a major source of DIC in the groundwater. Rather, $\delta^{13} \mathrm{C}_{\mathrm{DIC}}$ may undergo progressive equilibration with aquifer carbonate during sequential carbonate dissolution/precipitation reactions (e.g. de-dolomitisation). This is consistent with the increasing $\mathrm{Mg} / \mathrm{Ca}$ ratios observed along the flow path, along with increasing $\delta^{13} \mathrm{C}_{\mathrm{DIC}}$ values in the carbonate aquifer (see Fig. 7a), but no overall increase in $\mathrm{HCO}_{3}$ (Fig. 4 and Table 2). Near the coastline, the more enriched $\delta^{13} \mathrm{C}_{\mathrm{DIC}}$ values and lower DIC may also result due to mixing with seawater. An increasing trend in $\mathrm{SO}_{4}$ and $\mathrm{Mg}$ concentrations and $\mathrm{Mg} / \mathrm{Ca}$ ratios along the flow path is also indicative of de-dolomitisation (e.g. Jones et al., 1989; Plummer et al., 1990; López-Chicano et al., 2001; Szynkiewicz et al., 2012) in which the dissolution of gypsum and anhydrite leads to over-saturation and thus dolomite dissolution and calcite precipitation. For deeper carbonate groundwater underlying the Daweijia well field, the negative correlation between $\mathrm{Ca}^{2+}$ and $\delta^{13} \mathrm{C}_{\text {DIC }}$ (Fig. 7b) also indicates that $\mathrm{Ca}$ enrichment in groundwater may be not attributed to carbonate dissolution. The increase in $\delta^{13} \mathrm{C}$ with decreasing $\mathrm{Ca}$ content is likely related to the incongruent reaction, which removes $\mathrm{Ca}$ from solution and progressively increases $\delta^{13} \mathrm{C}$ to equilibrate with the aquifer matrix. In the Quaternary aquifer, the minor cal- 

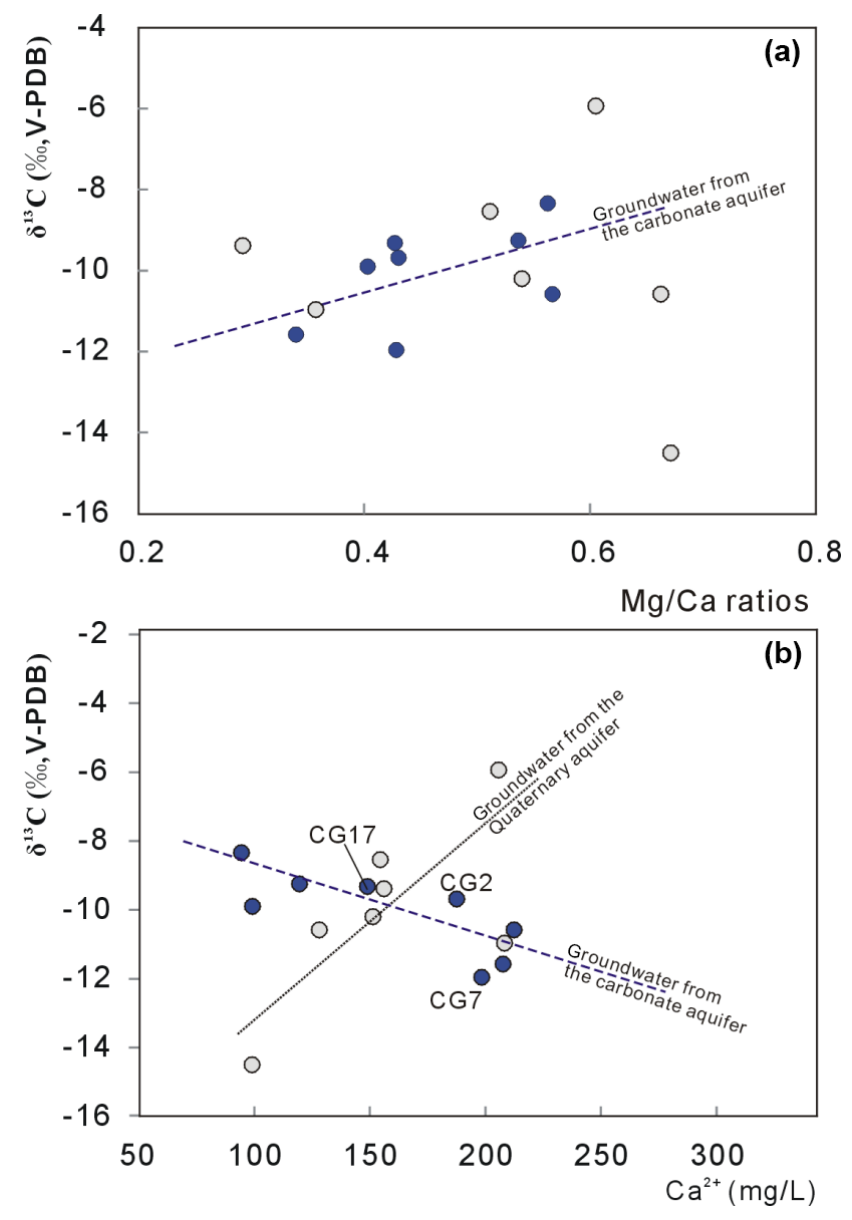

Figure 7. Graphs showing (a) $\mathrm{Mg} / \mathrm{Ca}$ ratios (by $\mathrm{meqL}^{-1}$ ); (b) $\mathrm{Ca}^{2+}$ concentrations vs. $\delta^{13} \mathrm{C}_{\mathrm{DIC}}$ values in different aquifers (grey - groundwater samples collected from the Quaternary aquifer; blue - groundwater samples collected from the carbonate aquifer). See Fig. 3 for legend.

cite dissolution occurring could lead to increasing $\delta^{13} \mathrm{C}$ with increasing $\mathrm{Ca}$. An alternative process may remove the $\mathrm{HCO}_{3}$ along flow paths (e.g. $\mathrm{CO}_{2}$ de-gassing).

Deines et al. (1974) showed that there are significant differences in the relationships between carbon isotopic composition and chemical variables for open and closed system conditions. Based on their model (which uses similar initial conditions to the study area) the chemical and isotopic composition of groundwater at a given $\mathrm{pH}$ in equilibrium with a reservoir of a given $P_{\mathrm{CO}_{2}}$ and $\delta^{13} \mathrm{C}_{\mathrm{r}}$ can be estimated. For the closed system model the ${ }^{13} \mathrm{C}$ content of the solution depends not only on the ${ }^{13} \mathrm{C} /{ }^{12} \mathrm{C}$ ratio of the reservoir $\mathrm{CO}_{2}$ $\left(\delta^{13} \mathrm{C}_{\mathrm{r}}\right)$, but also on that of the dissolving carbonate rock $\left(\delta^{13} \mathrm{C}_{\text {rock }}\right)$. The $\mathrm{pH}$ and $\delta^{13} \mathrm{C}$ values of the carbonate aquifer groundwater suggest evolution in a relatively closed system. Lower $\delta^{13} \mathrm{C}$ value $(-14.5 \%$ ) of shallow groundwater (QG4) in recharge area may be more affected by the soil $\mathrm{CO}_{2}$ in areas of intensive corn cultivation, ranging from approximately
-18 to $-25 \%$ (Deines et al., 1974). In this area, the irrigation using local carbonate groundwater may have resulted in mixing between the shallow groundwater with similar values to this, and the deep water from the carbonate aquifer (with higher values), leading to the intermediate value observed. Most groundwater in the study area is supersaturated with respect to calcite and dolomite (Han et al., 2015). The hydrochemical composition of groundwater is influenced by $\mathrm{CO}_{2}$ exsolution and $\mathrm{CaCO}_{3}$ precipitation, which can be described by the reaction

$\mathrm{Ca}^{2+}+2 \mathrm{HCO}_{3}^{-}=\mathrm{CaCO}_{3} \downarrow+\mathrm{CO}_{2}(\mathrm{~g}) \uparrow+\mathrm{H}_{2} \mathrm{O}$.

At isotopic equilibrium $\mathrm{CO}_{2}$ is enriched in ${ }^{12} \mathrm{C}$ and $\mathrm{CaCO}_{3}$ in ${ }^{13} \mathrm{C}$ with respect to $\mathrm{HCO}_{3}^{-}$(Deines et al., 1974). Since for each mole of $\mathrm{CO}_{2}$ exsolved one mole of $\mathrm{CaCO}_{3}$ is precipitated, the kinetic isotope effects is removal of ${ }^{12} \mathrm{C}$ enriched carbon from the solution, which concentrates ${ }^{13} \mathrm{C}$ in the remaining $\mathrm{HCO}_{3}^{-}$. The enrichment of $\delta^{13} \mathrm{C}_{\mathrm{DIC}}$ without change in $\mathrm{HCO}_{3}^{-}$content may thus be caused by ${ }^{12} \mathrm{CO}_{2}$ loss during exsolution and ${ }^{13} \mathrm{C}$ enrichment in solution. Dolomite dissolution is likely to add $\mathrm{Ca}^{2+}, \mathrm{Mg}^{2+}$, and $\mathrm{HCO}_{3}^{-}$to the solution, while calcite precipitation will remove DIC and retain calcite saturation, resulting in generally increasing $\mathrm{Mg} / \mathrm{Ca}$ ratios along flow paths, along with increasing $\delta^{13} \mathrm{C}$ values (Freeze and Cherry, 1979; Edmunds et al., 1987; Cardenal et al., 1994; Kloppmann et al., 1998). The dissolution of even very small amounts of gypsum may cause this process to occur in carbonate aquifers, which is usually characterised by near saturation with respect to calcite, by creating temporary under-saturation (due to the addition of calcium but not a bicarbonate ion) (Plummer et al., 1990; López-Chicano et al., 2001; Moral et al., 2008; Szynkiewicz et al., 2012).

Additionally, $\mathrm{Sr}$ is good proxy for $\mathrm{Ca}$ variations and sources with higher correlation, and the concentration of $\mathrm{Sr}^{2+}$ is often particularly high and frequently correlated with $\mathrm{SO}_{4}^{2-}$ concentrations (Fig. 8). In addition to Sr's origin from celestite, which may be present as microcrystalline inclusions in gypsum, $\mathrm{Sr}^{2+}$ can also occur as solid solution in carbonate minerals (Hunkeler and Mudry, 2007). Large amounts of anthropogenic chemical input will change these highly correlated relationships. Figure 8 shows different slopes in the relationship between $\mathrm{Cl}$ / TDS and $\mathrm{Sr}$ for different water types. The chloride-rich brackish water with high $\mathrm{Cl} / \mathrm{TDS}$ ratios has high $\mathrm{Sr}$ contents in the carbonate aquifer; in contrast, the sulfate-rich brackish water with low $\mathrm{Cl}$ / TDS has a wide range of $\mathrm{Sr}$ contents in the Quaternary aquifer. The higher $\mathrm{Sr}$ contents in the COA likely result due to enhanced from water-rock interaction (carbonate mineral dissolution), possibly enhanced by historic seawater intrusion.

Another possible control on the carbon chemistry of the groundwater is that active re-circulation of water is taking place in the unsaturated zone of the aquifer due to anthropogenic activity. In the local agricultural soils, $\mathrm{CO}_{2}$ concentration is usually high, with a $\delta^{13} \mathrm{C}_{\mathrm{DIC}}$ between -6.3 


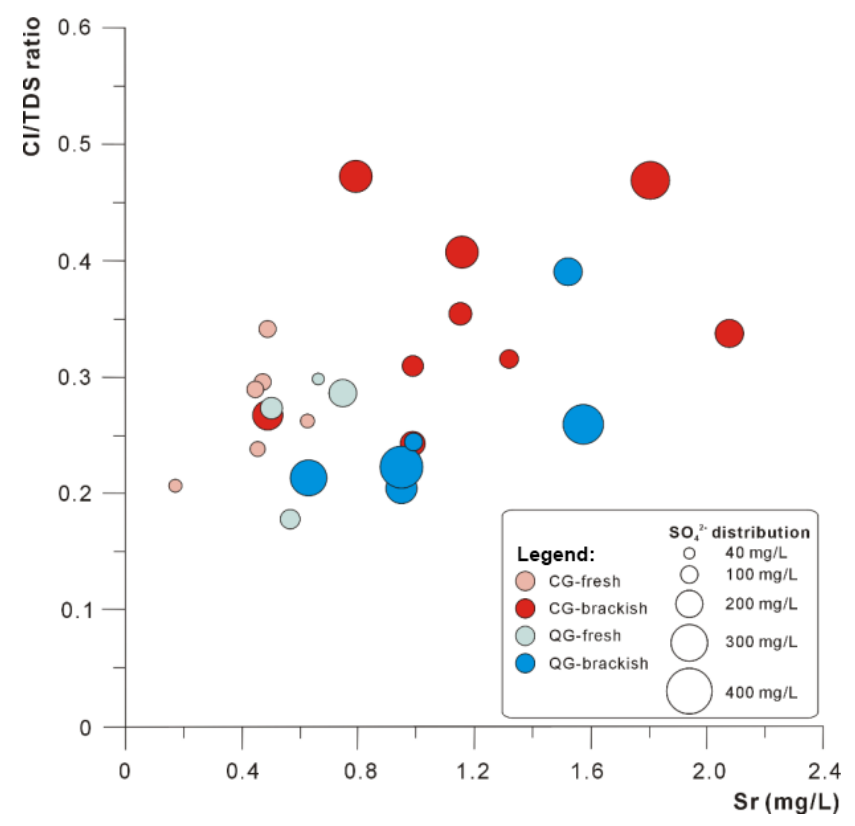

Figure 8. Plot of $\mathrm{Cl} / \mathrm{TDS}$ ratio vs. $\mathrm{Sr}\left(\mathrm{mg} \mathrm{L}^{-1}\right)$ from groundwater samples in the Daweijia area. Sulfate concentration of each sample is also indicated by the size of the point. CG - groundwater from the carbonate aquifer; QG - groundwater from the Quaternary aquifer.

and $-13.1 \%$ and $\delta^{13} \mathrm{C}$ of dissolved organic carbon between -23.2 and $-21.8 \%$ (Yang, 2011). During recharge events, water dissolves the soil $\mathrm{CO}_{2}$ which is involved in carbonate dissolution and becomes part of the DIC pool. If this process is conducted over successive irrigation, the $\mathrm{HCO}_{3}^{-}$concentration increases and $\delta^{13} \mathrm{C}_{\mathrm{DIC}}$ will deplete owing to the dissolved biogenic $\mathrm{CO}_{2}$ in soil.

\subsection{Sources of dissolved $\mathrm{SO}_{4}$ to groundwater}

Dissolved $\mathrm{SO}_{4}^{2-}$ of groundwater in the coastal aquifers might originate from several sources, potentially including (i) natural and artificial sulfates in rainwater, (ii) dissolution of sulfate-bearing evaporates (e.g. gypsum and anhydrite), (iii) seawater, and (iv) anthropogenic pollutants (e.g. domestic sewage, detergent and agricultural fertilisers). The $\delta^{34} \mathrm{~S}$ of groundwater $\mathrm{SO}_{4}$ are used as a tracer to identify the sources of dissolved $\mathrm{SO}_{4}^{2-}$ to the groundwater in this study. Figure 5 shows the relation between $\delta^{34} \mathrm{~S}_{\mathrm{SO}_{4}}$ values and $\mathrm{SO}_{4} / \mathrm{Cl}$ for groundwater samples, showing typical literature values for sulfur isotopic composition of major sulfate sources. Most of the water samples from the Daweijia area have sulfur isotopic compositions that reflect mixed sources. The ${ }^{34} \mathrm{~S}_{\mathrm{SO}_{4}}$ values are generally lower in the upstream area $(+5.4 \sim+5.7 \%$ ), increasing along the groundwater flow paths towards the coast $\left(+13.1 \%\right.$ o). Enrichment in $\delta^{34} \mathrm{~S}_{\mathrm{SO}_{4}}$ may result from sulfate reduction, whereas sulfide oxidation generally leads to negative $\delta^{34} \mathrm{~S}_{\mathrm{SO}_{4}}$ values (Clark and Fritz, 1997). However, there are no negative $\delta^{34} \mathrm{~S}_{\mathrm{SO}_{4}}$ values observed in this study area, indicating minor or negligible sulfide (such as pyrite) oxidation occurring in the aquifer.

$\delta^{34} \mathrm{~S}_{\mathrm{SO}_{4}}$ value of modern seawater is approximately $+21 \%$ (Rees et al., 1978). The $\delta^{34} \mathrm{~S}_{\mathrm{SO}_{4}}$ of groundwaters, ranging from +13.1 to $+5.4 \%$ with a mean value of $+8.9 \%$, thus generally discount this as a significant source of sulfate, consistent with the low mixing fractions calculated using $\mathrm{Cl}$. The $\delta^{34} \mathrm{~S}_{\mathrm{SO}_{4}}$ values of precipitation from eight stations in the northern region of the Yangtze River range from $+4.9 \%$ to $+11.0 \%$ o (Hong et al., 1994). Aside from CG1, the $\delta^{34} \mathrm{~S}_{\mathrm{SO}_{4}}$ compositions of the samples overlap with the isotopic range of rainfall. However, rainfall is characterised by higher $\mathrm{SO}_{4} / \mathrm{Cl}(2.26$, Zhang et al., 2012) than the groundwater $(0.16 \sim 0.97)$ and significantly lower total concentrations than are observed, indicating that this is only a partial origin of sulfate in groundwater. Sulfate minerals (gypsum, anhydrite, etc.) from marine sources typically have $\delta^{34} \mathrm{~S}_{\mathrm{SO}_{4}}$ values between +9 and $+30.2 \%$ o (Shi et al., 2004 ; Vitòria et al., 2004). As groundwater flows downwards into the deeper karst aquifer, the $\delta^{34} \mathrm{~S}$ values increase and approach the values in marine evaporites, part of the continuous de-dolomitisation reaction discussed above. However, this cannot explain the observed sulfate levels in the Quaternary aquifer (see mass balance calculations below).

Fertilisers have a wide range of $\delta^{34} \mathrm{~S}_{\mathrm{SO}_{4}}$ values ranging from -6.5 to $+11.7 \%$, with mean values of $+3.7 \%$ and $-0.8 \%$ in the Northern Hemisphere (Szynkiewicz et al., 2011) and China (Li et al., 2006), respectively. Apart from CG1 $\left(\delta^{34} \mathrm{~S}_{\mathrm{SO}_{4}}\right.$ value of $+13.1 \%$ ) , the $\delta^{34} \mathrm{~S}_{\mathrm{SO}_{4}}$ values of the rest groundwater samples are within the $\delta^{34} \mathrm{~S}_{\mathrm{SO}_{4}}$ ranges of known fertilisers. The isotopic $\delta^{34} \mathrm{~S}$ values in fertilisers significantly differ from the geological $\mathrm{SO}_{4}$ inputs of sedimentary origin, and overlap with most of the observed compositions (Fig. 5). In addition, the very high nitrate concentrations observed in the groundwater (up to $625 \mathrm{mg} \mathrm{L}^{-1}$ ) strongly indicate a high input of excess fertiliser residue via irrigation returns to the aquifer. This indicates that sulfate in fertilisers should be taken into account as a major contributing source of dissolved $\mathrm{SO}_{4}$ in groundwater, especially from the Quaternary aquifer. This is also confirmed by the general positive relationship between $\mathrm{NO}_{3}^{-}$and $\mathrm{SO}_{4}^{2-}$ concentrations (Fig. 9a) and correlation (albeit weak) between $\delta^{34} \mathrm{~S}$ values and $\mathrm{NO}_{3}$ concentrations in the Quaternary aquifer (Fig. 9b). It can be assumed that other anthropogenic sources of $\mathrm{SO}_{4}$ such as atmospheric deposition or detergents from domestic/wastewater sources, or pig manure are negligible in the study area.

Despite the clear overlap in $\delta^{34} \mathrm{~S}$ of fertilisers and groundwater $\mathrm{SO}_{4}^{2-}$, the $\delta^{34} \mathrm{~S}$ measured in upstream locations (e.g. QG3 and QG4) probably reflect inputs from geologic $\mathrm{SO}_{4}$ sources (such as soil sulfate) (Fig. 5). In contrast, the sulfur isotope values are more consistent with marine sedimentary sources of groundwater $\mathrm{SO}_{4}$ in the carbonate aquifer, due to the sustained water-rock interaction and longer resi- 

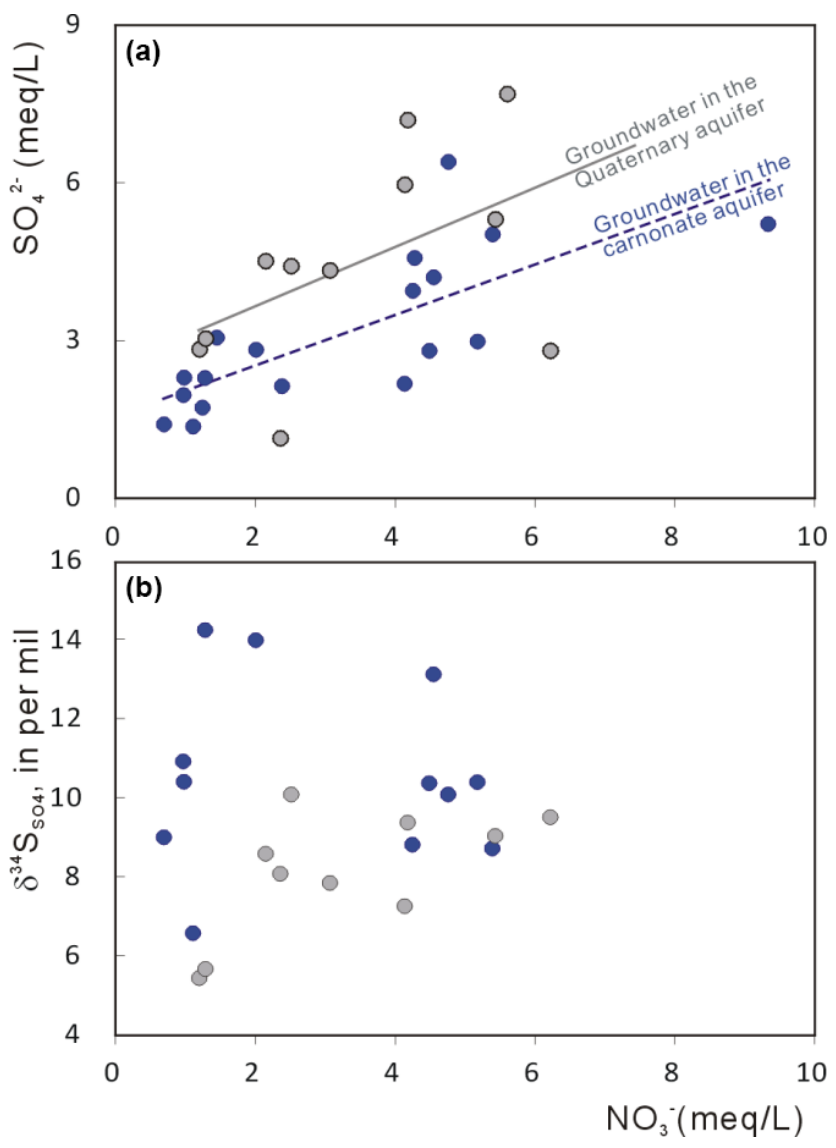

Figure 9. Bivariate plots for (a) relationship between $\mathrm{SO}_{4}^{2-}$ and $\mathrm{NO}_{3}^{-}$concentration and (b) $\delta^{34} \mathrm{~S}_{\mathrm{SO}_{4}}$ vs. $\mathrm{NO}_{3}^{-}$concentrations. See Fig. 2 for legend.

dence time. The evidence for gypsum dissolution as part of de-dolomitisation in the major ion and carbon isotope data (discussed above) is also consistent with a marine evaporite source of sulfur in the deeper aquifer.

Both $\delta^{13} \mathrm{C}$ and $\delta^{34} \mathrm{~S}_{\mathrm{SO}_{4}}$ values increase along the groundwater flow path (Table 3). Groundwater with low $\delta^{13} \mathrm{C}$ values (e.g. $-14.5 \%$ ) and $\delta^{34} \mathrm{~S}_{\mathrm{SO}_{4}}$ values (e.g. $\sim+5.4 \%$ ) represents recently recharged water, which is dominated by unsaturated zone processes and diffuse flow. Equilibration with carbonate minerals in the aquifer matrix during de-dolomitisation makes an important contribution to the groundwater $\delta^{13} \mathrm{C}$ evolution in the karst aquifer $\left(\delta^{13} \mathrm{C}\right.$ up to $-5.9 \%$ in QG11), reaching saturation with respect to calcite and dolomite. Then, the high loads of fertilisers accessible during agricultural return flow are the most likely source of the dissolved sulfate and nitrate, particularly in the shallow Quaternary aquifer.

\subsection{Anthropogenic contribution on groundwater chemistry and environmental implications}

Fertilisers are applied beyond what is taken up by crops in the long term in many parts of China (Davidson and Wei, 2012), as evident from the high $\mathrm{NO}_{3}^{-}$concentrations in groundwater. The wide range of $\mathrm{NO}_{3}^{-}$concentrations indicates considerable anthropogenic input under human activities (e.g. fertiliser usage during irrigation, leakage from septic system), which is responsible for the deterioration of local groundwater and near-shore seawater quality. $\mathrm{NO}_{3}^{-}$concentrations are obviously elevated (e.g. $75-386 \mathrm{mg} \mathrm{L}^{-1}$ ) in the shallow groundwater from the Quaternary aquifer, especially near the Daweijia well field, resulting from agricultural fertilisation. Due to nitrate input from fertilisers, the relatively low nitrate concentrations in some deep groundwater (e.g. CG4, CG14), which are located in the upstream area, show that, compared with groundwater in the downgradient area, these waters have locally reduced impacts from contamination. However, many deep groundwater samples have similar ranges of $\mathrm{NO}_{3}^{-}$ concentrations to shallow groundwaters, indicating that there is a hydraulic connection between shallow and deep aquifers (e.g. QG5 and CG7 in Fig. 2).

To quantify the fertiliser contributions to groundwater chemistry, we considered the inputs of precipitation infiltration, seawater intrusion and evaporite dissolution into groundwater system. We used a mass balance approach to evaluate the contribution of difference sources of sulfate to the dissolved $\mathrm{SO}_{4}^{2-}$ of groundwater. The four sources of sulfate in the dissolved $\mathrm{SO}_{4}^{2-}$ of groundwater are from precipitation, seawater, fertiliser and evaporate dissolution. The isotopic composition of groundwater sulfate $\left(\delta^{34} \mathrm{~S}_{\mathrm{SO}_{4}}\right)$ can be calculated by

$\delta^{34} \mathrm{~S}_{\mathrm{gw}} \times \mathrm{SO}_{4, \mathrm{gw}}=\delta^{34} \mathrm{~S}_{\text {prec }} \times \mathrm{SO}_{4, \mathrm{prec}}+\delta^{34} \mathrm{~S}_{\mathrm{sw}} \times \mathrm{SO}_{4, \mathrm{sw}}$
$+\delta^{34} \mathrm{~S}_{\text {fer }} \times \mathrm{SO}_{4, \text { fer }}+\delta^{34} \mathrm{~S}_{\mathrm{evp}} \times \mathrm{SO}_{4, \text { evp }}$,

where $\delta^{34} \mathrm{~S}_{\text {prec }}, \mathrm{SO}_{4, \text { prec }}, \delta^{34} \mathrm{~S}_{\mathrm{sw}}, \mathrm{SO}_{4, \mathrm{sw}}, \delta^{34} \mathrm{~S}_{\text {fer }}, \mathrm{SO}_{4, \mathrm{fer}}$, $\delta^{34} \mathrm{~S}_{\mathrm{evp}}$, and $\mathrm{SO}_{4, \text { evp }}$, correspond to the end member $\delta^{34} \mathrm{~S}$ values for rainfall $(+5.39 \%$, Hong et al., 1994), seawater $(+21 \%$, Clark and Fritz, 1997), fertiliser $(-0.8 \%$ o, Li et al., 2006), and sulfate marine evaporates of CambrianOrdovician age $(+28 \%$, Clark and Fritz, 1997). The dissolved $\mathrm{SO}_{4}^{2-}$ concentration $\left(\mathrm{SO}_{4, \mathrm{gw}}\right)$ in groundwater is the total sulfate contribution from precipitation, seawater, fertiliser and evaporate:

$\mathrm{SO}_{4, \mathrm{gw}}=\mathrm{SO}_{4, \mathrm{prec}}+\mathrm{SO}_{4, \mathrm{sw}}+\mathrm{SO}_{4, \text { fer }}+\mathrm{SO}_{4, \mathrm{evp}}$,

where

$\mathrm{SO}_{4, \mathrm{prec}}=\left[\mathrm{SO}_{4, \mathrm{prec}}\right] \times R=8.02 \mathrm{mg} \mathrm{L}^{-1} \times 0.783$
$\mathrm{SO}_{4, \mathrm{sw}}=\left[\mathrm{SO}_{4, \mathrm{sw}}\right] \times \mathrm{f}_{\mathrm{sw}}=2710 \mathrm{mg} \mathrm{L}^{-1} \times f_{\mathrm{sw}}$.

The $\mathrm{SO}_{4}^{2-}$ concentration $\left(\left[\mathrm{SO}_{4}\right.\right.$,prec $\left.]=8.02 \mathrm{mg} \mathrm{L}^{-1}\right)$ of the local precipitation was reported by Zhang et al., 2012, and 
Table 3. Characteristic ranges of $\delta^{13} \mathrm{C}$ and $\delta^{34} \mathrm{~S}_{\mathrm{SO}_{4}}$ values in groundwater and seawater (showing a vertically increasing trend) (see locations in Fig. 2).

\begin{tabular}{llllll}
\hline & $\begin{array}{l}\text { Shallow } \\
\text { groundwater from } \\
\text { upperstream } \\
\text { area (A1) }\end{array}$ & $\begin{array}{l}\text { Deep } \\
\text { groundwater from } \\
\text { upperstream } \\
\text { area (A2) }\end{array}$ & $\begin{array}{l}\text { Shallow } \\
\text { groundwater from } \\
\text { downstream } \\
\text { area (B1) }\end{array}$ & $\begin{array}{l}\text { Deep } \\
\text { groundwater from } \\
\text { downstream } \\
\text { area (B2) }\end{array}$ & Seawater (C) \\
\hline$\delta^{13} \mathrm{C}(\% \circ, \mathrm{V}-\mathrm{PDB})$ & -14.5 to -13.5 & -12.8 to -9.0 & -11.0 to -5.9 & -9.7 to -10.6 & -1 to +2 \\
$\delta^{34} \mathrm{~S}_{\mathrm{SO}_{4}}(\% \circ, \mathrm{CDT})$ & 5.4 to 5.7 & 9.0 to 10.9 & 7.2 to 10.1 & 8.7 to 13.1 & 21 \\
\hline
\end{tabular}

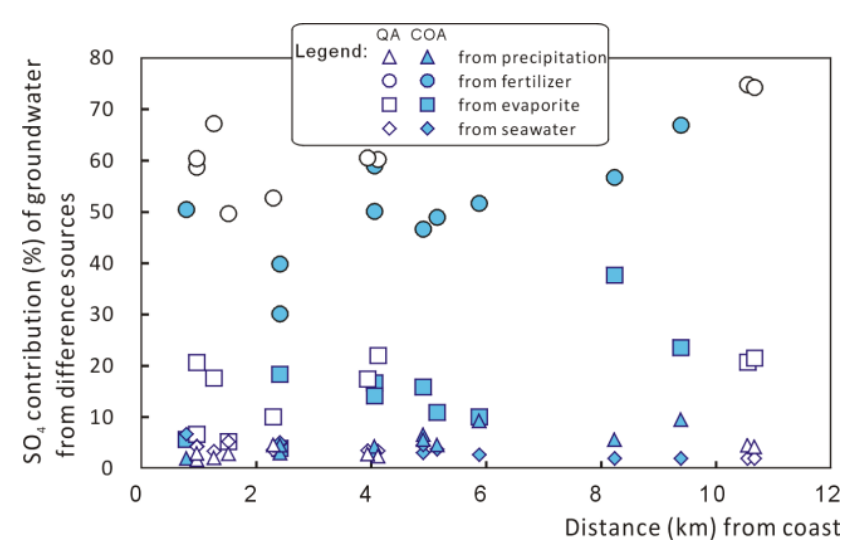

Figure 10. Calculated $\mathrm{SO}_{4}^{2-}$ contribution of groundwater from four different sources (QA - groundwater from the Quaternary aquifer; $\mathrm{COA}$ - groundwater from the carbonate aquifer).

$\mathrm{SO}_{4}^{2-}$ concentration $\left(\left[\mathrm{SO}_{4, \mathrm{sw}}\right]=2710 \mathrm{mg} \mathrm{L}^{-1}\right)$ of the seawater referenced from Clark and Fritz (1997). $R$ is the recharge rate equal to the ratio of the amount of precipitation infiltration and the amount of the total groundwater resources in the study area. According to the water balance calculations in the local groundwater flow system (CGS, 2007), groundwater is mainly recharged from precipitation infiltration, which occupied $78.3 \%(R)$ of the total recharge water volume. $f_{\mathrm{sw}}$ can be calculated by Eq. (1) for each groundwater sample.

The results of the mass balance, showing sulfate contribution to groundwater from fertiliser (assuming these end members correspond to values in the study area) are shown in Fig. 10. In total, 4 to $22 \%$ of the dissolved $\mathrm{SO}_{4}^{2-}$ concentrations in groundwater are contributed from evaporite dissolution, whereas 30 to $75 \%$ of the dissolved $\mathrm{SO}_{4}^{2-}$ concentrations in groundwater can be ascribed to input from fertilisers. According to these calculations, overall, the local application of the fertilisers is now responsible for the majority of dissolved $\mathrm{SO}_{4}^{2-}$ in groundwater. The contribution reaches on average $62.1 \%$ in the Quaternary aquifer and $48.7 \%$ in the deeper carbonate aquifer, showing that the shallow Quaternary aquifer is particularly prone to pollution by fertiliser utilisation. The sulfate contributions to groundwater from seawater and precipitation are less than $10 \%$, which is relatively lower and is consistent with the observation that pumping restrictions have effectively halted saline intrusion in the area. We analysed the sensitivity of the mass balance by changing $\pm 10 \%$ of the end-member sulfur isotope compositions of fertiliser and evaporate, respectively. We found that the change in $\delta^{34} S_{\text {fer }}$ varied the contributions from fertiliser and evaporate by \pm 0.1 and $\pm 0.2 \%$, respectively. The $\pm 10 \%$ change in $\delta^{34} S_{\text {evp }}$ leads to changes in the contributions from fertiliser and evaporate by \pm 0.4 and $\pm 2 \%$, respectively. This suggests that the results are more sensitive to $\delta^{34} S_{\text {evp }}$ values in the mass balance.

Although further investigation is needed to determine the contribution of dissolved sulfate from different pollution sources (the end-member values used above are naturally uncertain and may bias the overall \% contributions), the current results indicate that the anthropogenic contaminant input plays a dominant role in providing sulfate to the shallow groundwater (as well as nitrate), and that this influence has extended into the deeper carbonate aquifer. This widespread shift towards agricultural return flow becoming the dominant control on groundwater chemistry, particularly in shallow aquifers, is consistent with what is unfolding over many areas of north China (Currell et al., 2012). This is a disturbing trend, particularly given the time lags involved in groundwater systems equilibrating towards new water quality norms, which suggest significant future degradation of groundwater resources will continue to occur in these areas.

\section{Conclusions}

The coastal aquifer in the Daweijia area, northeast China, is composed of interlayered Quaternary sedimentary and Cambrian-Ordovician carbonate rocks. The groundwater has evolved from freshwater (meteoric recharge) to brackish water in a series of water types: $\mathrm{Ca}(\cdot \mathrm{Mg})-\mathrm{HCO}_{3} \cdot \mathrm{Cl} \rightarrow \mathrm{Ca} \cdot$ $\mathrm{Na}-\mathrm{Cl} \cdot \mathrm{HCO}_{3} \rightarrow \mathrm{Ca}-\mathrm{Cl} \rightarrow \mathrm{Na} \cdot \mathrm{Ca}-\mathrm{Cl} \rightarrow \mathrm{Na}-\mathrm{Cl}$ via a combination of natural and anthropogenic processes. After the cessation of the groundwater pumping in the Daweijia well field, the TDS concentration of groundwater has increased; however, the $\mathrm{Cl}^{-}$concentrations have not, and in some areas have decreased. The major change has been large increases in $\mathrm{SO}_{4}^{2-}$ and $\mathrm{NO}_{3}^{-}$concentrations, which have increased several times compared to 1981 . This indicates that the local government efforts to restrict groundwater abstraction have been ef- 
fective in their purpose of limiting saline intrusion; however, water quality degradation has continued due to a new source, nitrate and sulfate contamination, largely resulting from the heavy application of agricultural fertilisers.

There are the increasing trends of $\delta^{13} \mathrm{C}_{\mathrm{DIC}}$ and $\delta^{34} \mathrm{~S}_{\mathrm{SO}_{4}}$ values for groundwater along the flow path. The enrichment of $\delta^{13} \mathrm{C}_{\mathrm{DIC}}$ of groundwater may be caused by kinetic isotope effects as most groundwater is super-saturated with respect to calcite and dolomite, which can cause ${ }^{12} \mathrm{CO}_{2}$ loss during exsolution and ${ }^{13} \mathrm{C}$ enrichment in solution. The $\mathrm{pH}$ and $\delta{ }^{13} \mathrm{C}$ values of the investigated groundwater suggest evolution in a closed system. The potential sources of dissolved $\mathrm{SO}_{4}^{2-}$ in the coastal aquifers include natural and artificial sulfates in rainwater, dissolution of sulfate evaporates (e.g. gypsum and anhydrite), seawater, and anthropogenic pollutants (e.g. agricultural fertilisers). We estimated the contributions of the four different sources of the dissolved sulfate in groundwater quality by using the mass balance approach. Apart from seawater and precipitation (less than $10 \%$ ), the fertiliser contribution in sulfate concentrations of groundwater could be as high as an average of $62.1 \%$ in the Quaternary aquifer, and $48.7 \%$ in the deeper carbonate aquifer, depending on the end-member composition used. Although the processes that affect the groundwater quality and the contribution to the dissolved sulfate of groundwater in the Daweijia area should be further evaluated by more investigation (such as nitrogen isotope data), the current research results obtained from a set of geochemical and isotopic tools show that the sulfate contribution from fertiliser application, compared with that from seawater intrusion and precipitation infiltration, is dominant, with a secondary source from long-term evaporite dissolution and de-dolomitisation as water equilibrates with the carbonate aquifer matrix.

Also, there are similar ranges of $\mathrm{NO}_{3}^{-}$concentrations, isotopic compositions $\left(\delta^{13} \mathrm{C}_{\mathrm{DIC}}\right.$ and $\left.\delta^{34} \mathrm{~S}_{\mathrm{SO}_{4}}\right)$ and water type in the shallow Quaternary and deeper carbonate aquifers in most parts of the study area, indicating interaction between shallow and deep groundwater in the study area, which has implications for aquifer protection from contamination by agricultural chemicals.

Coastal carbonate aquifers, a prolific groundwater source worldwide, are characterised by rapid groundwater circulation and recharge and are therefore highly vulnerable to anthropogenic contamination. Human activities in heavily populated areas such as the current study are now potentially the key driver in the hydrology and hydrochemical evolution of some of these coastal aquifers, as demonstrated here. Only by strictly controlling anthropogenic land-use and water-use activities can the pollution and degradation of these aquifers be prevented. Future studies could focus on the seasonal variation of sulfur and nitrogen isotopes of dissolved $\mathrm{SO}_{4}^{2-}$ and $\mathrm{NO}_{3}^{-}$, respectively, and more detailed analysis of these stable isotopes in soil profiles. This could provide more insight into the dynamics of contamination of this and other similar aquifers.

Acknowledgements. This research was partially funded by Zhu Kezhen Outstanding Young Scholars Program (no. 2015RC102), Institute of Geographic Sciences and Natural Resources Research, Chinese Academy of Sciences. It was undertaken as part of a groundwater survey project entitled "Assessment of Vulnerability and Investigation of Environmental Geology in the Key Section of Circum-Bohai-Sea Region”. The authors are grateful to Yang Jilong, Liu Xin, Xie Hailan and Pan Tong for their help and support during water sampling and monitoring in the field and data collection. We also want to acknowledge the constructive suggestions from Ian Cartwright and another anonymous reviewer.

Edited by: C. Stumpp

\section{References}

Appelo, C. A. J.: Cation and proton exchange, $\mathrm{pH}$ variations and carbonate recactions in a freshening aquifer, Water Resour. Res., 30, 2793-2805, 1994.

Appelo, C. A. J. and Postma, D.: Geochemistry, groundwater and pollution, 2nd Edn., A. A. Balkema Publishers, Leiden, the Netherlands, 241-246, 2005.

Aunay, B., Dörfliger, N., Duvail, C., Grelot, F., Le Strat, P., Montginoul, M., and Rinaudo, J. D.: Hydro-socio-economic implications for water management strategies: the case of Roussillon coastal aquifer, in: International Symposium - DARCY 2006, Aquifer Systems Management, May 2006, Dijon, France, p. 9, 2006.

Back, W., Hanshaw, B. B., Pyle, T. E., Plummer, L. N., and Weidie, A. E.: Geochemical significance of groundwater discharge and carbonate solution of the formation of Caleta Xel Ha, Quintana Roo, Mexico, Water Resour. Res., 15, 1521-1535, 1979.

Barlow, P. M. and Reichard, E. G.: Saltwater intrusion in coastal regions of North America, Hydrogeol. J., 18, 247-260, 2010.

Cardenal, J., Benavente, J., and Cruz-Sanjulián, J. J.: Chemical evolution of groundwater in Triassic gypsum-bearing carbonate aquifers (Las Alpujarras, southern Spain), J. Hydrol., 161, 3-30, 1994.

Cartwright, I., Weaver, T. R., Fulton, S., Nichol, C., Reid, M., and Cheng, X.: Hydrogeochemical and isotopic constraints on the origins of dryland salinity, Murray Basin, Victoria, Australia, Appl. Geochem., 19, 1233-1254, 2004.

CGS - China Geology Survey: Assurance report of water supply in Dalian City, Geological survey institute of Liaoning Province, Dalian, China, 38-44, 2007.

Clark, I. and Fritz, P.: Environmental Isotopes in Hydrogeology, Lewis Publishers, Boca Raton, 138-140, 1997.

Cravotta, C. A.: Use of Stable Isotopes of Carbon, Nitrogen, and Sulfur to Identify Sources of Nitrogen in Surface Waters in the Lower Susquehanna River Basin, Pennsylvania, US Geol. Surv. Water Supply Paper, US Geological Survey, Denver, 2038,1995 .

Currell, M. J., Cartwright, I., Bradley, D. C., and Han, D. M.: Recharge history and controls on groundwater quality in the Yuncheng Basin, north China, J. Hydrol., 385, 216-229, 2010. 
Currell, M. J., Han, D. M., Chen, Z. Y., and Cartwright, I.: Sustainability of groundwater usage in northern China: dependence on palaeowaters and effects on water quality, quantity and ecosystem health, Hydrol. Process., 26, 4050-4066, 2012.

Daniele, L., Vallejos, Á., Corbella, M., Luis Molina, L., and PulidoBosch, A.: Hydrogeochemistry and geochemical simulations to assess water-rock interactions in complex carbonate aquifers: The case of Aguadulce (SE Spain), Appl. Geochem., 29, 43-54, 2013.

Deines, P. and Langmuir, D.: Stable carbon isotope ratios and the existence of a gas phase in the evolution of carbonate ground waters, Geochim. Cosmochim. Acta, 38, 1147-1164, 1974.

de Louw, P. G. B., Eeman, S., Oude Essink, G. H. P., Vermue, E., and Post, V. E. A.: Rainwater lens dynamics and mixing between infiltrating rainwater and upward saline groundwater seepage beneath a tile-drained agricultural field, J. Hydrol., 501, 133-145, 2013.

de Montety, V., Radakovitch, O., Vallet-Coulomb, C., Blavoux, B., Hermitte, D., and Valles, V.: Origin of groundwater salinity and hydrogeochemical processes in a confined coastal aquifer: Case of the Rhône delta (Southern France), Appl. Geochem., 23, 2337-2349, 2008.

Drever, J. I.: The Geochemistry of Natural Waters: Surface and Groundwater Environments, Prentice-Hall, New Jersey, USA, 436 pp., 1997.

Edmunds, W. M.: Bromine geochemistry of British groundwaters, Mineral. Mag., 60, 275-284, 1996.

Edmunds, W. M., Cook, J. M., Darling, W. G., Kinniburgh, D. G., and Miles, D. L.: Baseline geochemical conditions in the chalk aquifer, Berkshire, UK: a basis for groundwater quality management, Appl. Geochem., 2, 251-274, 1987.

Fan, J. J.: Seawater intrusion and calculation of groundwater exploitation in the karst area of the west JinXian, Dalian, Hydrogeol. Eng. Geol., 1, 3-6, 1984.

Freeze, R. A. and Cherry, J. A.: Groundwater, Prentice Hall, Englewood Cliffs, NJ, 604 pp., 1979.

Ghassemi, F., Jakeman, A. J., and Nix, H. A.: Salinisation of land and water resources: human causes, extent, management and case studies, University of New South Wales Press, Sydney, 526 pp., 1995.

Ghiglieri, G., Carletti, A., and Pittalis, D.: Analysis of salinization processes in the coastal carbonate aquifer of Porto Torres (NW Sardinia, Italy), J. Hydrol., 432-433, 43-51, 2012.

Giménez-Forcada, E.: Dynamic of sea water interface using hydrochemical facies evolution diagram, Ground Water, 48, 212-216, 2010.

Guo, Y. H., Shen, Z. L., and Zhong, Z. X.: Downward movement of shallow saline groundwater and its impact on deep-lying groundwater system, Hydrogeol. Eng. Geol., 2, 8-12, 1995.

Halas, S. and Szaran, J.: Low-temperature thermal decomposition of sulfates to $\mathrm{SO}_{2}$ for on-line ${ }^{34} \mathrm{~S} /{ }^{32} \mathrm{~S}$ analysis, Analyt. Chem., 71, 3254-3257, 1999.

Han, D. M., Kohfahl, C., Song, X. F., Xiao, G. Q., and Yang, J. L.: Geochemical and isotopic evidence for palaeo-seawater intrusion into the south coast aquifer of Laizhou Bay, China, Appl. Geochem., 26, 863-883, 2011.

Han, D. M., Post, V. E. A., and Song, X. F.: Groundwater salinization processes and reversibility of seawater intrusion in coastal carbonate aquifers, J. Hydrol., 531, 1067-1080, 2015.
Hong, Y. T., Zhang, H. B., Zhu, Y. X., Pu, H. C., Jiang, H. B., and Liu, D. P.: Characteristics of sulfur isotope composition of precipitation in China, Adv. Nat. Sci., 6, 741-745, 1994.

Hosono, T., Nakano, T., Iget, A., Tayasu, I., Tanaka, T., and Yachi, S.: Impact of fertilizer on a small watershed of Lake Biwa: Use of sulfur and strontium isotopes in environmental diagnosis, Sci. Total Environ., 384, 342-354, 2007.

$\mathrm{Hu}$, T.: Analysis on economic benefit of Dalian suburban farming, Chin. Agr. Sci. Bull., 26, 393-397, 2010.

Hunkeler, D. and Mudry, J.: Hydrochemical methods, in: Methods in karst hydrogeology: IAH international contributions to hydrogeology, edited by: Goldscheider, N. and Drew, D., British Geological Survey, Wallingford, UK, Taylor \& Francis Group eLibrary, London, UK, 99 pp., 2007.

Jin, Y. J. and Wu, Q.: The application of the electrical logging of well fluid in determining the vertical heterogeneity of sea water intrusion. J. Heibei College Geol., 13, 69-73, 1990.

Jones, B., Pleydell, S. M., Ng, K.-C., and Longstaffe, F. J.: Formation of poikilotopic calcite-dolomite fabrics in the OligoceneMiocene Bluff formation of Grand Cayman, British West Indies, Bull. Can. Petrol. Geol., 37, 255-265, 1989.

Kaown, D., Koh, D.-C., Mayer, B., and Lee, K.-K.: Identification of nitrate and sulphate sources in groundwater using dual stable isotope approaches for an agricultural area with different land use (Chuncheon, mid-eastern Korea), Agr. Ecosyst. Environ., 132, 223-231, 2009.

Kim, H., Kaown, D., Mayer, B., Lee, J., Hyun, Y., and Lee, K.: Identifying the sources of nitrate contamination of groundwater in an agricultural area (Haean basin, Korea) using isotope and microbial community analyses, Sci. Total Environ., 533, 566575, 2015.

Kloppmann, W., Dever, L., and Edmunds, W. M.: Residence time of chalk groundwaters in the Paris Basin and the North German Basin: a geochemical approach, Appl. Geochem., 13, 593-606, 1998.

Kumar, M., Rao, M. S., Deka, J. P., Ramanathan, A. L., and Kumar, B.: Integrated hydrogeochemical, isotopic and geomorphological depiction of the groundwater salinization in the aquifer system of Delhi, India, J. Asian Earth Sci., 111, 936-947, 2015.

Langmuir, D.: The geochemsitry of some carbonate ground waters in central Pennsylvania, Geochim. Cosmochim. Acta, 35, 1023$1045,1971$.

Li, X. D., Harue, M., Kusakabe, M., Yanagisawa, F., and Zeng, H. A.: Degradation of groundwater quality due to anthropogenic sulfur and nitrogen contamination in the Sichuan Basin, China, Geochem. J., 40, 309-332, 2006.

López-Chicano, M., Bouamama, M., Vallejos, A., and PulidoBosch, A.: Factors which determine the hydrogeochemical behavior of karst springs. A case study from the Betic Cordilleras, Spain, Appl. Geochem., 16, 1179-1192, 2001.

Lü, G., Zhao, L. B., Sun, X. Z., and Tan, D. F.: Periodic summary report on investigating the environmental hydrogeology in Dalian area, The Second Institute of hydrogeology and engineering geology, Liaoning Bureau of Geology, Dalian, China, 48-66, 1981.

McCaffrey, M. A., Lazar, B., and Holland, H. D.: The evaporation path of seawater and the coprecipitation of $\mathrm{Br}^{-}$and $\mathrm{K}^{+}$with halite, J. Sediment. Petrol., 57, 928-937, 1987.

Moral, F., Cruz-Sanjulian, J. J., and Olias, M.: Geochemical evolution of groundwater in the carbonate aquifers of Sierra de Se- 
gura (Betic Cordillera, southern Spain), J. Hydrol., 360, 281296, 2008

Myshakin, E., Siriwardane, H., Hulcher, C., Lindner, E., Sams, N., King, S., and McKoy, M.: Numerical simulations of vertical growth of hydraulic fractures and brine migration in geological formations above the Marcellus shale, J. Nat. Gas Sci. Eng., 27, 531-544, 2015.

Najib, S., Fadili, A., Mehdi, K., Riss, J., Makan, A., and Guessir, H.: Salinization process and coastal groundwater quality in Chaouia, Morocco, J. Afr. Earth Sci., 115, 17-31, 2016.

Otero, N., Canals, A., and Soler, A.: Using dual-isotope data to trace the origin and processes of dissolved sulphate: a case study in Calders stream (Llobregat basin, Spain), Aquat. Geochem., 13, 109-126, 2007.

Parkhurst, D. L. and Appelo, C. A. J.: User's Guide to PHREEQC-A Computer Program for Speciation, Reaction-Path, 1D-Transport, and Inverse Geochemical Calculation, US Geol. Surv. WaterResour. Invest. Rep., US Geol. Surv., Denver, Colorado, 994259, 1999.

Plummer, L. N. and Sprinkle, C. L.: Radiocarbon dating of dissolved inorganic carbon in groundwater from confined parts of the Upper Floridan Aquifer, Florida, USA, Hydrogeol. J., 9, 127150, 2001.

Plummer, L. N., Busby, J. F., Lee, R. W., and Hanshaw, B. B.: Geochemical modeling in the Madison aquifer in parts of Montana, Wyoming and South Dakota, Water Resour. Res., 26, 1981-2014, 1990.

Rees, C. E.: The sulphur isotopic composition of ocean water sulphate, Geochim. Cosmochim. Acta, 42, 377-381, 1978.

Sánchez-Martos, F., Pulido-Bosch, A., Molina-Sánchez, L., and Vallejos-Izquierdo, A.: Identification of the origin of salinization in groundwater using minor ions (Lower Andarax, Southeast Spain), Sci. Total Environ., 297, 43-58, 2002.

Schiavo, M. A., Hauser, S., and Povinec, P. P.: Stable isotopes of water as a tool to study groundwater-seawater interactions in coastal south-eastern Sicily, J. Hydrol., 364, 40-69, 2009.

Shi, Z. S., Chen, K. Y., Shi, J., He, H. J., and Liu, B. J.: Sulfur isotopic composition and its geological significance of the Paleogene sulfate rock deposited in Dongpu Depression, Petrol. Explor. Dev., 31, 44-46, 2004.

Song, Q. C.: Status quo of seawater intrusion in Daweijia karst water source of Dalian, China, J. Chengdu Univers. Technol., 40, 348-352, 2013.
Szynkiewicz, A., Witcher, J. C., Modelska, M., Borrok, D. M., and Pratt, L. M.: Anthropogenic sulfate loads in the Rio Grande, New Mexico (USA), Chem. Geol., 283, 194-209, 2011.

Szynkiewicz, A., Newton, B. T., Timmons, S. S., and Borrok, D. M.: The sources and budget for dissolved sulfate in a fractured carbonate aquifer, southern Sacramento Mountains, New Mexico, USA, Appl. Geochem., 27, 1451-1462, 2012.

Unland, N. P., Taylor, H. L., Bolton, B. R., and Cartwright, I.: Assessing the hydrogeochemical impact and distribution of acid sulphate soils, Heart Morass, West Gippsland, Victoria, Appl. Geochem., 27, 2001-2009, 2012.

Vitòria, L., Otero, N., Soler, A., and Canals, À.: Fertilizer characterization: Isotopic Data (N, S, O, C, and Sr), Environ. Sci. Technol., 38, 3254-3262, 2004.

Vogel, J. C.: Variability of carbon isotope fractionation during photosynthesis, in: Stable Isotopes and Plant Carbon - Water Relations, edited by: Ehleringer, J. R., Hall, A. E., and Farquhar, G. D., Academic Press, San Diego, CA, 29-38, 1993.

$\mathrm{Wu}$, Q. and Jin, Y. J.: Characteristics of seawater intrusion in coastal karst groundwater system of Daweijia area, Dalian City, Geotech. Invest. Survey., 3, 43-44, 1990.

Wu, Q., Jin, Y. J., Li, D. A., and Xia, Y. H.: The mechanisms of seawater intrusion of karst groundwater system in Daweijia, Dalian City and the countermeasures of its control, Chin. J. Geol. Hazard Control, 1, 64-68, 1994.

Yang, J. L.: Hydrogeochemical reactions in seawater intrusion process in Daweijia water source area, Dalian City, Master's degree thesis, Jilin University, Changchun, China, 14-15, 2011.

Zhang, X. Y., Jiang, H., Zhang, Q. X., and Zhang, X.: Chemical characteristics of rainwater in northeast China, a case study of Dalian, Atmos. Res., 116, 151-160, 2012.

Zhao, C. R., Yang, J. L., Xiao, G. Q., Du, D., Pan, T., and Zhang, S. F.: Hydrogeochemical reactions and hydrogeological model for seawater intrusion processes in the Daweijia water source area Dalian City, Geol. Surv. Res., 35, 154-160, 2012.

Zhao, T. S.: Problems of karst groundwater development in littoral area and its ultimate control method, Chin. J. Geol. Hazard Control, 4, 73-77, 1991. 